Article

\title{
Construction and Destruction of Bontău Composite Volcano in the Extensional Setting of Zărand Basin during Miocene (Apuseni Mts., Romania)
}

\author{
Ioan Seghedi *(1), Viorel M. Mirea and Gabriel C. Ștefan
}

check for

updates

Citation: Seghedi, I.; Mirea, V.M.;

Ștefan, G.C. Construction and Destruction of Bontău Composite Volcano in the Extensional Setting of Zărand Basin during Miocene (Apuseni Mts., Romania). Minerals 2022, 12, 243. https://doi.org/ $10.3390 / \min 12020243$

Academic Editors: Ján Spišiak, Jaroslav Pršek and Jiří Sejkora

Received: 14 January 2022

Accepted: 11 February 2022

Published: 14 February 2022

Publisher's Note: MDPI stays neutral with regard to jurisdictional claims in published maps and institutional affiliations.

Copyright: (c) 2022 by the authors. Licensee MDPI, Basel, Switzerland. This article is an open access article distributed under the terms and conditions of the Creative Commons Attribution (CC BY) license (https:// creativecommons.org/licenses/by/ $4.0 /)$.
Institute of Geodynamics Sabba S. Stefănescu, Romanian Academy, Endogenous Processes, 020032 Bucharest, Romania; vmirea@geodin.ro (V.M.M.); gabriel.stefan.geologie@gmail.com (G.C.Ș.)

* Correspondence: seghedi@geodin.ro

\begin{abstract}
The Eastern part of the Miocene Zărand extensional basin witnessed the generation and evolution of the largest composite volcano in Apuseni Mts., named recently Bontău. The volcano is filling the basin at the junction between the South and North Apuseni Mountains. The Bontău Volcano is known to be active roughly between $~ 14-10$. In spite of heavily forested and poorly exposed volcanic deposits, it was possible to identify its complex evolution. The volcano suggests an original oval-shaped edifice base currently showing a north-oriented horseshoe-shaped debris avalanche eroded crater. The early effusive volcanic activity was contemporaneous with the emplacement of individual and/or clustered volcanic lava Domes. Late-stage summit dome generation was followed by several volcanic collapses all around the volcanic edifice producing large volcanic debris avalanche deposits (DADs), accompanied by numerous debris flows all around the volcano periphery. Thick pumice pyroclastic flow deposits found below DADs at the periphery may suggest that the slope failures were proceeded by a Plinian eruption. The debris avalanche crater is the last event in the volcano evolution exposing several intrusive andesitic-dioritic bodies and associated hydrothermal and mineralization processes, most probably including the former central vent area of the volcano. The volcano proximal effusive and explosive deposits display a change in the composition of the erupting magma (increased $\mathrm{SiO}_{2}$ from $53.4 \%$ to $60.6 \%$ ) that resulted in an increase of viscosity and the construction of the summit lava domes. Such domes are however only found as various size blocks in DADs. The volcanism connects with the two steps of geotectonic evolution of the Zărand Basin: The initial construction period during regional extension started 16 Ma up to 12.3-12.1 when the Bontău volcano and surrounding domes were generated. The second period, younger than $12 \mathrm{Ma}$, corresponds to NW-SE compressional tectonics developed only in the Bontău volcano with summit dome generation and, finally, assists volcano destruction and DADs generation. Newly performed geochemical and $\mathrm{Sr}$ and $\mathrm{Nd}$ isotopic data studies attest to a calc-alkaline character and suggest an evolution via assimilation-fractional crystallization processes of a dominant MORB-like mantle source magma. Also, they confirm the amphibole ( \pm pyroxene) andesites to be the most evolved lithology. The stepwise changes in fracture propagation in the Zărand extensional setting along with a change to more hydrated and fractionated magma favored in $\sim 4$ Myrs of the evolution of the Bontău volcano lead to multiple pulses of the longest-lived magma chamber in the whole Miocene volcanism of the Apuseni Mts.
\end{abstract}

Keywords: composite volcano; debris avalanche; Apuseni Mountains; andesite; extensional setting; Miocene

\section{Introduction}

This study is dedicated to the Bontău volcanic complex, the major known andesitic composite volcano (e.g., [1]) and associated lava Dome structures that were rising inside the largest graben system in the southern part of the Apuseni Mts. during Middle-Late 
Miocene, known transnationally as Békés-Zărand basin, or nationally as Zărand basin (e.g., [2,3]; Figure 1). Recent field data acquisition along with additional rock sampling have led to a novel volcanological and petrological interpretation. The area is heavily forested, and the volcanic deposits are poorly exposed, principally, on the major valleys and forest roads that cross the volcano edifice; close to the north of the volcano, east to west directed, there are several complex extrusive lava Domes, most of them heavily quarried along the present-day Criş River (Figures 2 and 3). This is the reason we have major difficulties presenting a detailed volcanological study, most likely to be completed in future detailed studies. It's most impressive feature and novelty is given by the presence of four volcanic collapse events that strongly modified the initial volcano shape. Slope failures and/or multiple failures are better known since 1980 with the eruption of Mount St. Helens [4,5]. They are common events in the history of many andesitic volcanoes all over the world with numerous published articles (e.g., [6] and references therein). Our case is a rare example of an andesitic volcano generating and filling with its products a graben system, a situation somehow similar to Quaternary volcanism in the Trans-Mexican volcanic belt where various rifts have been generated, developing inside the volcanic activity, specifically at Colima (e.g., [7] and references therein; [8]) or Jocotitlán [9] volcanoes where numerous gravitational collapse deposits occurred post-rift. Here, we present for the first time, the distribution of debris-avalanche deposits to improve the knowledge of the number of failure events that have occurred at the Bontău volcano as an attempt to enhance the understanding of the evolution of the volcanism in the western part of the Zărand basin and make progress in understanding volcano evolution in a graben system. The volcanological observations are sustained by petrography, major and trace element geochemistry, Sr and $\mathrm{Nd}$ isotopes of the main volcanic rock types.

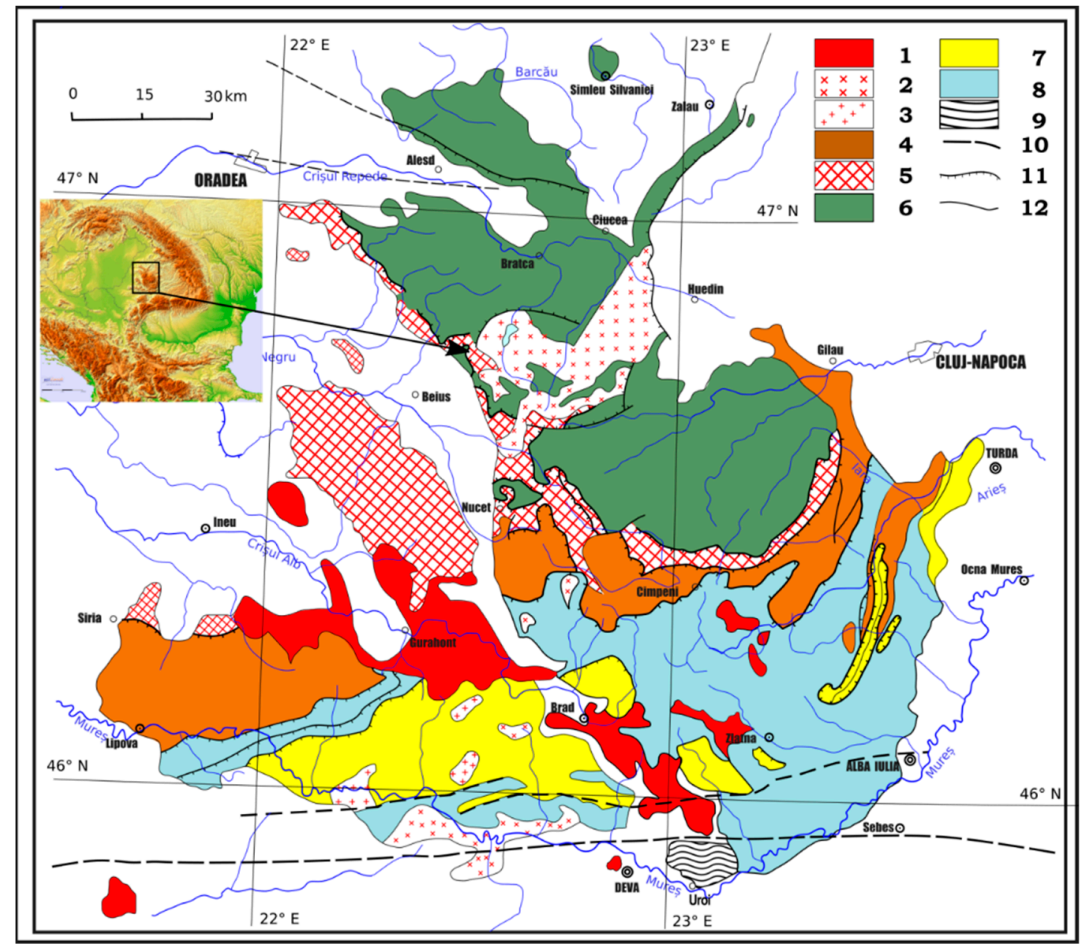

Figure 1. Geological map of Apuseni Mountains compiled and simplified after [10,11] with modifications. Legend: 1. Miocene-Pliocene magmatic rocks, 2. Upper Cretaceous-Paleocene Magmatic rocks (Banatites), 3. Upper Jurassic Granitoids. The North Apuseni Units: 4. Biharia Nappe Complex, 5. Codru Nappe Complex, 6. Bihor Nappe Complex; The South Apuseni Units (Transylvanide): 7. Upper Jurassic tholeiitic ophiolites and calc-alkaline island arc magmatic rocks and, in places, limestone, 8. Cretaceous sedimentary rocks, 9. Supragetic Units, 10. South Transylvanian Fault system, 11. Nappes, 12. Faults. 


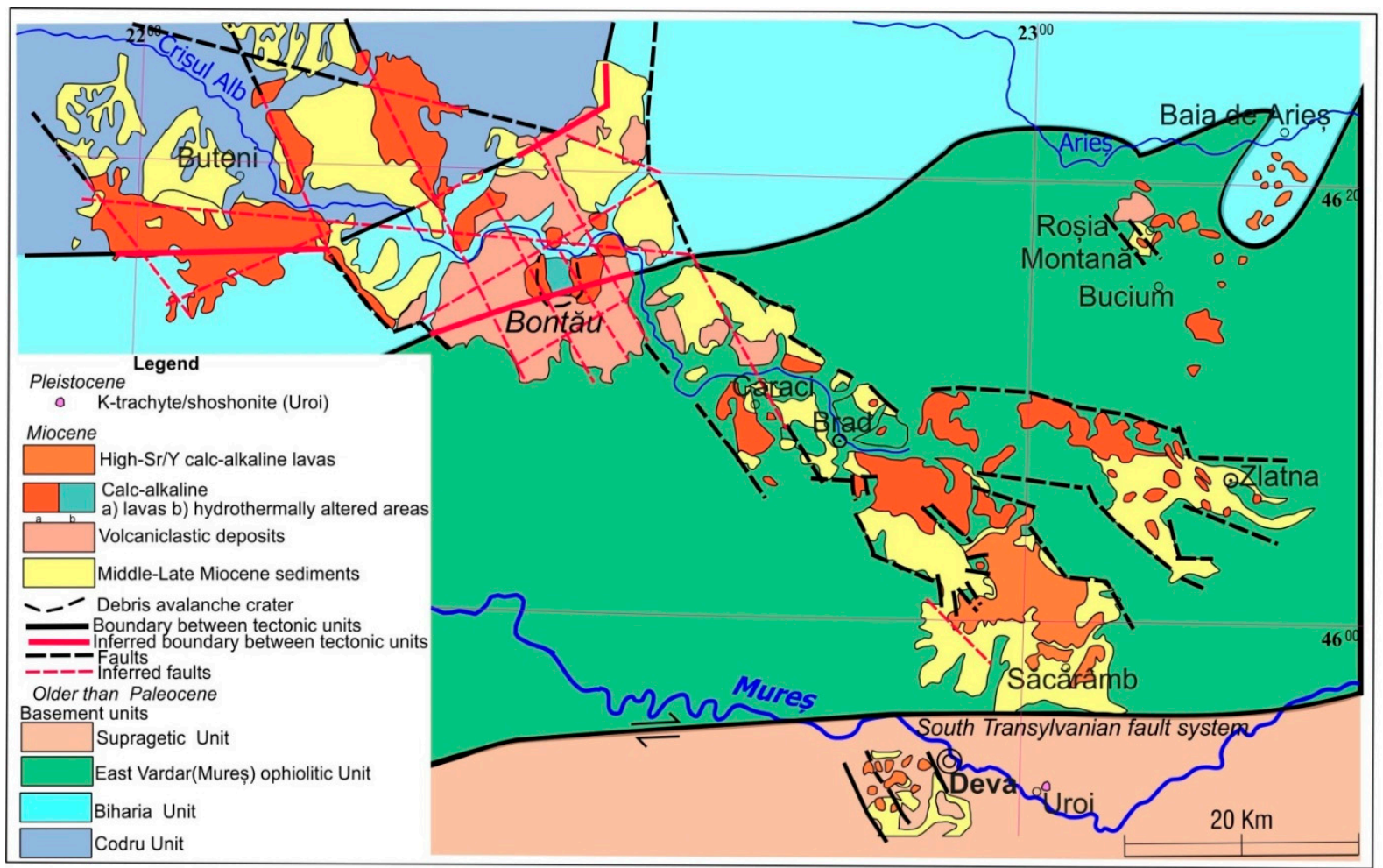

Figure 2. Sketch of Miocene magmatic rock occurrences in the NW-SE graben of the Zărand basin in the South Apuseni Mts. without Quaternary cover (after Geological map of Romania 1:1,000,000 and [3] with modifications). Bontău volcanic area is shown.

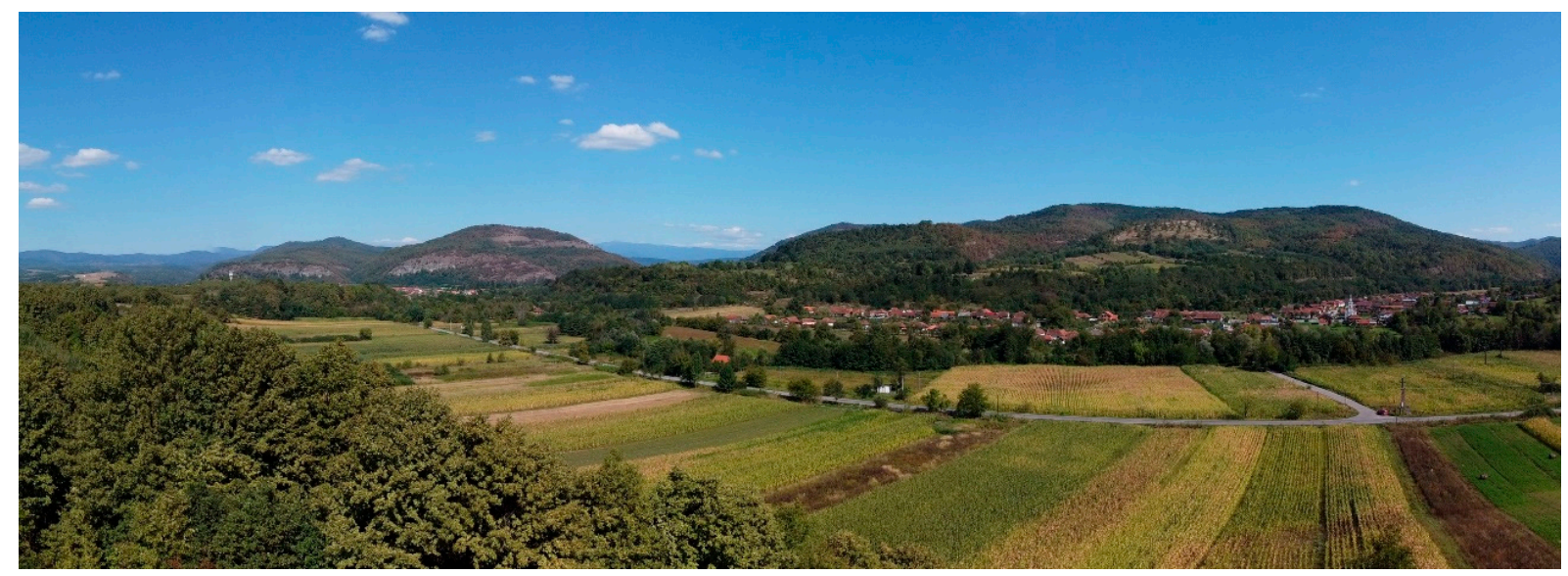

Figure 3. N-S photo panorama taken with a drone from the western side of the Bontău volcano (to the right) inside the Zărand basin viewing toward the left two Dome structures. The closest one to the volcano is named here as Gurahonţ, after the closest town.

\section{Methodology}

In order to reconstruct the magmatic evolution, we took observations directly from the deposits in the field covering a large area of $\sim 800$ square $\mathrm{Km}$. It was difficult to acquire a decent geological map or to obtain rigorous stratigraphic correlations of the volcanic and volcaniclastic deposits due to poor exposure. This is the reason we used digital elevation models (DEM) that help geological mapping with geomorphic observations. More than 150 thin sections of rock (lava, dome, intrusions, and clasts in volcaniclastic deposits) samples were studied under a polarizing microscope. A total of 34 samples were analyzed for the whole rock major and trace elements (Table 1) at ALS Geochemistry 
Laboratories located at ALS Loughrea, Ireland (analytical methods, are indicated in the Supplementary Table S1). Sr and Nd-isotope ratios with 2SD were determined for 12 rock samples representative of different units (Supplementary Table S2). For Sr and Nd isotope ratios the samples were prepared by alkali fusion digestion at ALS Scandinavia AB, Luleá, Sweden. The analyses were carried out by MC-ICP-MS (Neptune Plus, Thermoscientific) after ion-exchange separation. SD was calculated from two independent consecutive measurements. Preparation blank contribution is below $0.05 \%$ of $\mathrm{Nd}$ and below $0.1 \%$ of $\mathrm{Sr}$ content in the sample.

\section{Local Geology and the Knowledge Summary}

The Miocene evolution of the Apuseni Mts. is characterized by the generation of several extensional graben-like structures, opened along its western edge (from north to south: Derecske-Borş-Borod, Beiuş and Békés-Zărand; e.g., [12,13]; Figure 1). Their formation assumes low-angle detachments with footwall exhumation controlling half grabens that disclosed deep crustal rocks [13-16]. The sedimentary graben infill (tens of meters up to a few $\mathrm{km}$; e.g., [17,18] and references therein; [19] is associated with volcanic activity only in the main Békés-Zărand basin and some small associated basins [3,20-22], where the geophysical data suggest asthenosphere upwelling up to $40-45 \mathrm{~km}$ depth $[14,23]$. The onset of extension began in Middle Miocene (i.e., $16 \mathrm{Ma}$ ) when subsequent normal faulting and further activation of listric normal faults is related to brittle tectonics and clockwise rotation of the hanging walls coeval with the main collapse phase of the Pannonian Basin (e.g., [12,13,24,25] and finished during Late Miocene (Figure 2)).

The local basement geology underneath Bontău volcano crops out at its southern part (Mureş ophiolitic unit) and to the north (Biharia and Codru units) (Figure 2) which shows a Variscan polymetamorphic basement [26-29] with Late Carboniferous and Permian granitic intrusions [27,30]. The volcano is situated at the limit between Mureş ophiolitic unit and Biharia unit (Figure 2). The inferred fault systems that considered the alignment of the main extrusive bodies and the prolongation of the basement faults suggest two main directions: (1) NNW-SSE, as the main local normal faults suggested to be associated with the $~ 16-12$ Ma tectonic rotations, (2) NW-SE normal fault system mostly developed after $\sim 12 \mathrm{Ma}$ when rotations ceased, assumed to a change to the NW-SE contraction direction (e.g., [3,31], (3) NE-SW directed normal/transtensional faults are frequent underneath the main Bontău volcano edifice and are generally parallel with the boundary between the main tectonic units, as developed from the marginal fragmentation of the Mureş ophiolitic unit on contact with the Biharia unit (Figure 2). This complex tectonic system initiated by rotations with extension/transtension was responsible for the long-time build-up of a $\sim 4$ Myers ( 14-10 Ma; [2,20]) Bontău calc-alkaline volcano.

\section{Description of the Volcanic Complex}

The volcanic succession considers the main volcanic forms and their distribution that have been generated in the western part of the Zărand basin (e.g., [32]). There are two of them: (1) individual/complex volcanic Domes sometimes showing an initial pyroclastic activity that mostly characterizes the western margin of the Zărand basin and are aligned with the main fault systems and (2) the Bontău volcano composite edifice surrounded by debris avalanche and associated debris flow deposits situated at the limit between Biharia Unit and East Vardar (Mureş) ophiolitic unit (Figures 3 and 4). 


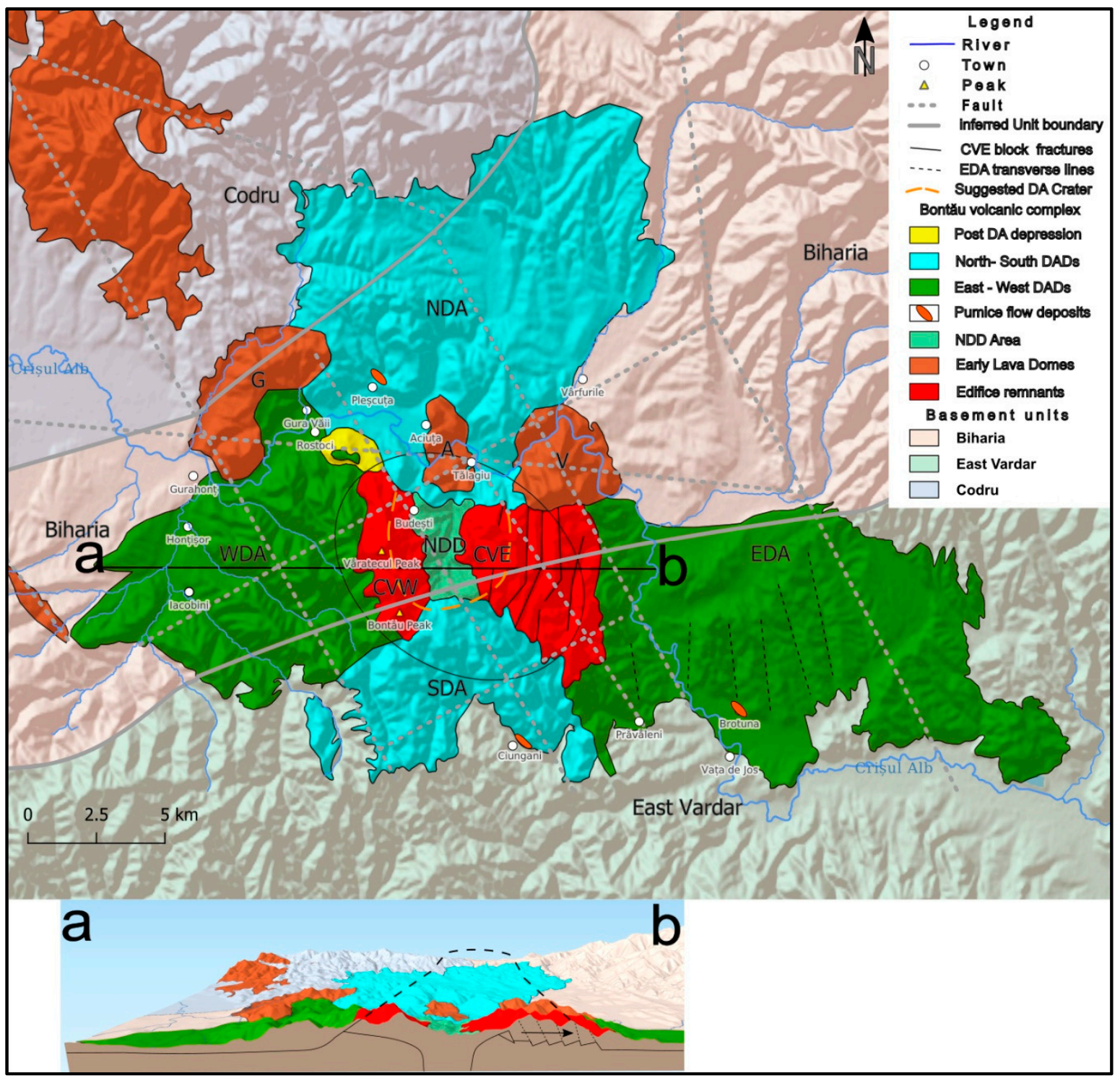

Figure 4. Volcanological features of the Bontău volcanic complex without Quaternary deposits. Lava Domes structures: Gurahonț $(\mathrm{G})$, Aciuța $(\mathrm{A})$ and a $(\mathrm{V})$; remnants of volcanic edifice: central area of debris-avalanche crater, described as non-differentiated deposits (NDD); western composite volcano edifice remnant (CVW); eastern composite volcano edifice remnant (CVE); NDA, SDA, WDA, EDA: northern, southern, western and eastern debris avalanche units. The oval shape suggests the assumed initial edifice base of the volcano. The 3D profile below $(\mathbf{a}-\mathbf{b})$, as shown on the map, is suggesting with a dashed line the possible initial shape of the volcano.

\subsection{Lava Dome Structures (LDS)}

The domes are a steep-sided mass of viscous lavas over a vent (e.g., [33]). The andesitic domes are characteristic volcanic forms growing at the margins of the Zărand basin as linear chains but also along the main E-W or NW-SE system inside the basin up to the eastern margin of the Bontău volcano (Figure 2). They are considered early domes different from the late-stage domes belonging to the Bontău volcano that is dominated by the amphibole ( \pm pyroxene) andesites. They are mostly clustering along the faults, but individual ones, showing typical conical structures, are morphologically individualized. Based on geological field mapping and digital elevation models, the individual domes have a diameter of $2-4 \mathrm{~km}$ and a variable slope angle between $17-30^{\circ}$. All the domes situated to the west of the Bontău volcano are surrounded by meter to dm-sized pumice and block pyroclastic flow deposits, which are products of the Vulcanian type explosions associated with the dome growth that 
is in a succession with angular clast-supported breccia layers, suggesting their origin from dome failure and fragmentation mostly as block and ash flow deposits (Figure 5a; details in Supplementary Figure S1a). Sometimes parallel/cross-bedded variables sort whitish tuff and lapilli tuffs, proposing surge or fallout events suggest a phreatomagmatic origin (Supplementary Figure S1a,b). The majority of the domes are andesitic, mostly pyroxenebearing. The fan-shaped bodies of outwardly thinning dominant pyroclastic breccias ringing around western domes are related to numerous successions of dome growth and destruction (e.g., [34,35]; Figure 5a). It looks like the domes from the western part of the Zărand basin are characterized by an initial Vulcanian pyroclastic phase (Figure 5b), sometimes phreatomagmatic with low-height and volume tephra columns governed by a variable volatile content, continued with dome growing up to the final viscous phase, showing a more or less circular base shape and conical-shaped protrusion suggestive of low volatile, slow-growing rate and solidification of the magma.
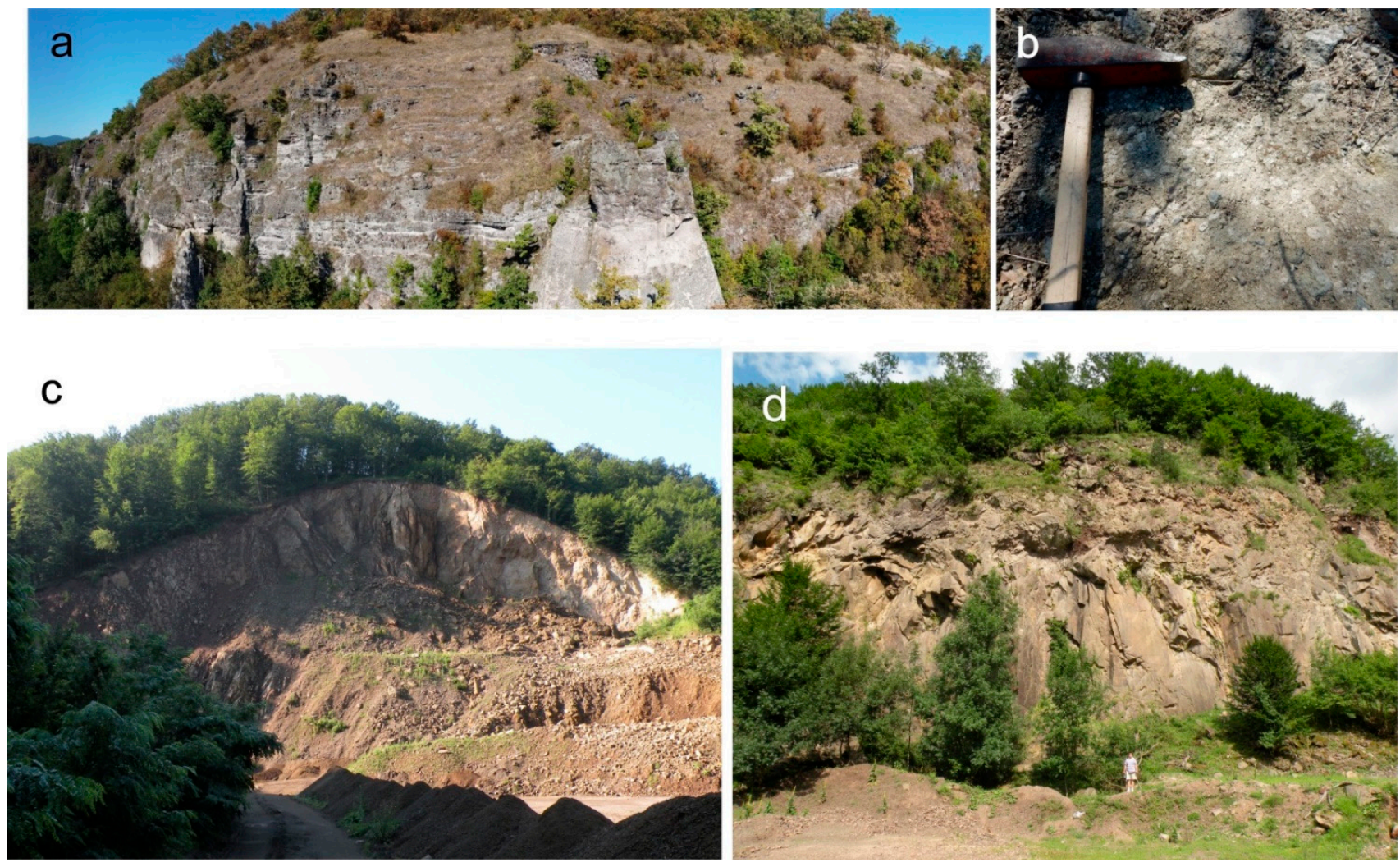

Figure 5. Geological features of the LDS: (a) Panoramic view of southern marginal part of the Gurahonţ lava Dome complex; the view is showing 50 m sequence of dm-m multiple layered deposits discernible by their whitish color. The whitish color indicates the pumice occurrence. The sequence belongs to the initiation of domes characterized by an initial multiple small-size Vulcanian explosive events and dome collapse; (b) Detail of a matrix-supported meter-sized deposit showing $\mathrm{cm}-\mathrm{dm}$ sized angular andesitic clast and pumice, indicative of pumice and block ash flow deposits; (c) Detail with vertical jointing in one of the Gurahonţ lava dome complex at Gura Văii; (d) Frequently vertical jointing at the margin of Vârfuri lava Dome complex in the top with marginal breccias at Vârfuri railroad station.

At the northern side of the Bontău volcano, there are three Dome complexes named Gurahonţ, Aciuţa, and Vârfuri after the main close-by towns (Figures 4 and 5). The internal structures of the Gurahonţ, Aciuţa, and Vârfuri lava Domes display typical vertical cooling jointing exposed in quarries (Figures 5c,d and S1c,d). Their outer marginal shell, when observable and not already eroded, shows fragmentation and generation of breccias 
(Figure 5d). Rarely such domes show associated collapse events and small size debrisavalanche deposits (e.g., Gurahonţ lava Dome complex near Gura Văii town).

The age of the Lava Domes as known from K/Ar determinations is between 12.3-13.0 Ma $[2,20,36]$.

\subsection{Bontău Volcano Edifice Remnants}

The initial edifice of the volcano is presently not conserved. The edifice remnants are situated at the south of the alignment of Gurahonţ, Aciutsa, and Vârfuri Dome complexes. It is composed of two edifice fragments of the composite volcano, one to the west (CVW) and one to the east (CVE) that have in between them a central area of non-differentiated deposits (NDD) variously affected by hydrothermal alterations (Figure 4). The age of the volcano edifice activity according to published $\mathrm{K} / \mathrm{Ar}$ data is between 10.2-13.8 Ma [2,20,36,37].

\subsubsection{The Central Area of Non-Differentiated Deposits (NDD)}

NDD area was previously considered a deeply eroded and enlarged vent area and attributed to a "caldera" resulting via volcano collapse [38]. According to the performed drillings in the communist era, the area displays a deep-sited diorite-microdiorite intrusion associated with pervasive hydrothermal alteration and gold, base metals, and copper uneconomic mineralization, also surrounded by variably fresh or altered necks and dykes of pyroxene or amphibole-pyroxene andesites [39,40] Recent explorations show also the presence of hydrothermal breccias in this area [41].

This deep area is irregularly elongated in the north-south direction, without showing an obvious crater-like shape; its floor is incised by a valley that is lowering toward the north and, at its prolongation, is followed by debris-avalanche deposits and secondary associated debris flow deposits. Several altered rocks have been found as components of north-oriented debris-avalanche deposits (Supplementary Figure S2c). These observations are in favor of a north-oriented horseshoe-shaped debris avalanche crater $(3.7 \mathrm{~km} \times 1.5 \mathrm{~km})$ and since it is the most evident, it is inferred as the youngest in the destructive processes of the volcano. It is most probable that this area may represent, before its destruction, a central part of the volcano between CVE and CVW, closer to the location of the original vent of the volcano since of numerous dykes and a large hydrothermal system situated in its center [39-41].

\subsubsection{The Western Composite Volcano Edifice Remnant (CVW)}

This part has an irregular shape, north-south-elongated $(5.0 \mathrm{~km} \times 3.3 \mathrm{~km})$ bordering the NDD area to the east (Figure 4) and it is constituted in its lower part by a sequence of basaltic andesite and pyroxene andesite lava flows (Figure 6a), sometimes associated with pyroclastic deposits (pumice/scoria-ash flows). At the top, several lava dome clusters can be supposed, as either pyroxene andesite or pyroxene-amphibole andesite in composition (Figure 6a). CVW has the current highest peaks called Văratec $(881 \mathrm{~m})$ to the north and Bontău $(859 \mathrm{~m})$ to the south, whose name was recently used for the volcano [2] instead of previous name Tălagiu [38] after a town at the north of NDD.

This remnant edifice is surrounded by debris-avalanche deposits (DAD), the most significant being the westernmost one (Figure 4). 

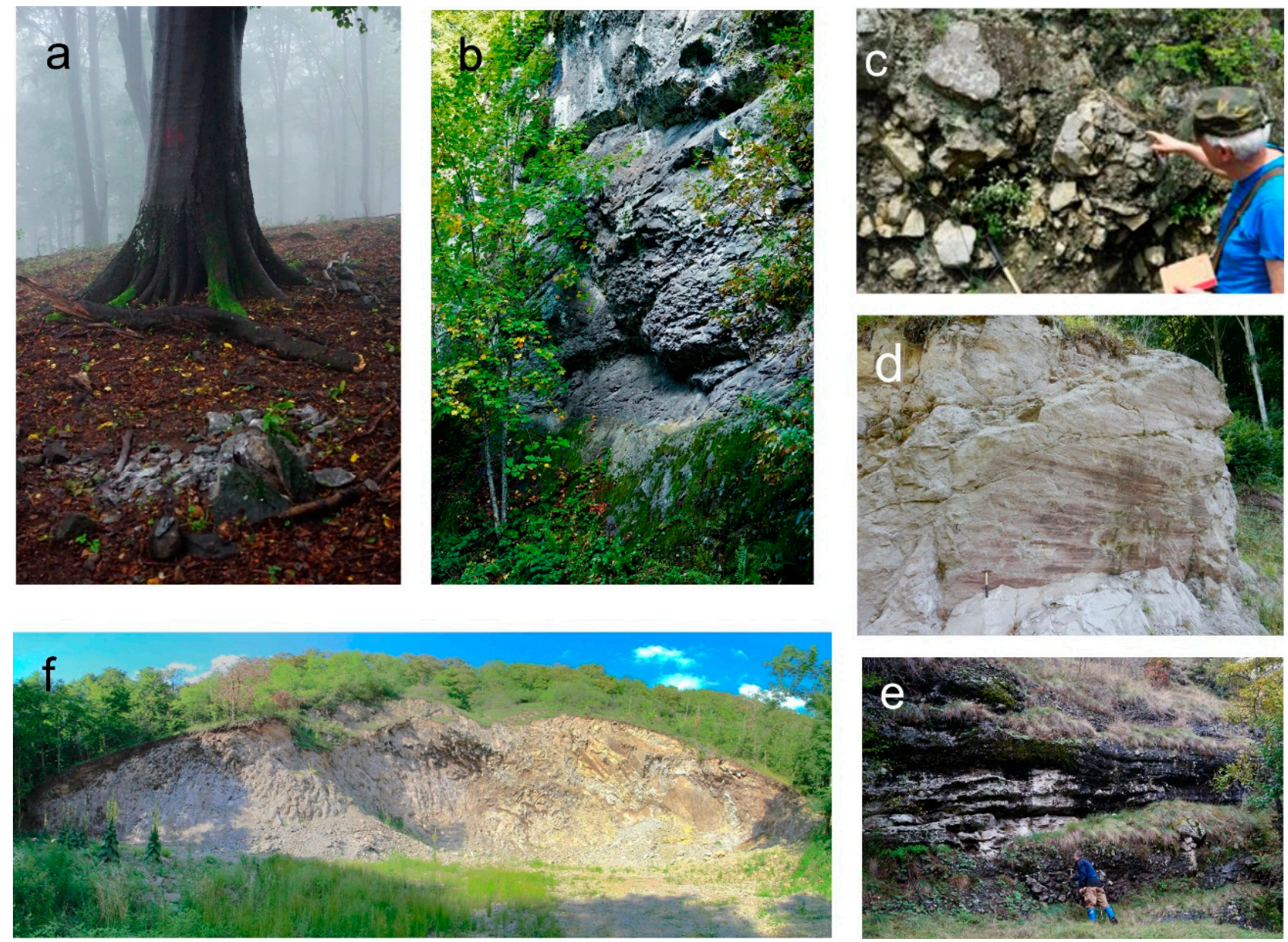

Figure 6. (a) Small lava dome outcrop exposed in the top of Văratec peak; to note poor exposure; (b) Succession of pyroxene andesite lava flows on the Bontău valley (CVW part of the volcano); (c) Outcrop of block facies debris-avalanche deposit viewing exclusive angular blocks and clasts of various sizes, some of them showing jigsaw cracks (WDA); (d) Several meters clast in block facies debris avalanche showing sub-horizontal slickenside (WDA); (e) Sequences in stratified debris flows deposits, of dm to m size, (WDA); (f) quarry in a strongly deformed and crushed large dome-type colossal block (150 m wide) of amphibole ( \pm pyroxene) andesite (WDA).

\subsubsection{The Eastern Composite Volcano Edifice Remnant (CVE)}

This fragment of the initial volcano is dissected by north-south oriented longitudinal ridges, the highest being at 740-720 $\mathrm{m}$ altitude, indicative of an eastern spreading direction. Considering the poor outcrop exposure, within the ridges, the stratigraphic succession was preserved, dominated by lava flows mostly pyroxene andesites and less pyroxene amphibole or amphibole ( \pm pyroxene) andesites (Figure $6 \mathrm{~b}$ ). The entire block can be fitted as one coherent part of the edifice (Figure $4 a-b$ profile). The valleys are oriented in the same N-S direction with the ridges up to the limit with the Vârfuri dome system where suddenly their orientation changes toward the east. The current valley system is suggesting amid ridges fault orientation (see profile $a-b$, Figure 4 ). At the slopes of this fragment, there is a gradual transition to debris-avalanche and associated debris flows and occasional block and ash flow deposits. This eastern fragment looks like a very large landslide block of the volcano, currently showing over $100 \mathrm{~m}$ lesser elevation than the CVW and it may represent a large collapse block rather than genuine remnants of the initial volcano. However, it is difficult to evaluate its real position since it looks dismembered at contact with the younger horseshoe-shaped debris avalanche crater described earlier as an NDD, which is mostly parallel with the block ridges along the same N-S direction. 


\subsection{General Features of the Debris Avalanche Deposits (DADs)}

This is the first description of the debris avalanche deposits (DADs) belonging to the Bontău volcano. Such deposits cover an extensive area around the former volcano edifice. Four such kinds of units have been separated, all filling the graben system of the Zărand basin and cut later in Quaternary by the Criş River (Figure 4). Two of them are E-W directed (EDA, WDA) and the other two N-S directed (NDA, SDA) surrounding the remnants of the former volcanic edifice presented above. The compositions are ranging from basaltic andesite to amphibole ( \pm pyroxene)-bearing andesites as the most evolved. The evolved type was only found in all the debris-avalanche deposits, rarely in the CVE edifice remnant, and always suggested to be appropriate to the dome volcanic form.

\subsubsection{The WDA Unit}

The WDA is characterized in the proximal part by either block facies (characterized by strongly fragmented rocks dominantly from domes, lava flow, and less pyroclastic material; Figure 4). The dimensions of the individual, deformed blocks vary between 150-1 m showing various degrees of fragmentation up to a sandy or very fine matrix (Figures 6c,d,f, and S2a). Most clasts are blocky angular, while some show jigsaw texture and are petrographically identical with the fragmented matrix. Meter-sized slickensides are mostly vertical suggesting, besides fragmentation, block rotations with a perpendicular axis along the slope (Figure $6 \mathrm{~d})$. In a medial to distal part ( $\sim 6 \mathrm{~km}$ from the vent), an association of debris-avalanche with debris-flow deposits of massive or reversely graded, conglomerates, rarely breccias and $\mathrm{cm}-\mathrm{dm}$ size sandstones showing irregular bed geometry with frequent channeling and scour surfaces in succession with sandstones (Figures 6e and S2b,d). The sole presence of large blocks of amphibole bearing andesites that portray lava domes of higher viscosity only in the debris-avalanche deposits (Figure 6f) may suggest that the edifice failure wiped out these dome formations that most probably have been situated at the top of the volcano, inferred to be much higher than in the present, not taking in consideration almost 10 Myers of erosional processes. The lack of evidence of any edifice scar for the WDA can be explained by the generation and further failure of high viscosity domes at the top of the volcano, which are also associated with block and ash, and Plinian pyroclastic eruptions favored the dome edifice collapse. At the medial-distal part of WDA, rare outcrops several meters in thickness of stratified thin planar and crossbedded sandstone and siltstone were observed, which are different from the epiclastic debris flows generated at the medial-distal part with DADs. These epiclastic deposits are well to moderately sorted, commonly showing low angle cross lamination in lenses or pockets, suggesting hyper-concentrated flow deposits (Figure 7a). Rare large angular andesite blocks can be also identified. Since such deposits do not show significant lateral extension ( 10-50 $\mathrm{m}$ ) and are bordered by DADs, they have been interpreted as post DADs intra-hummocky small basins. Such kinds of deposits have been found in all the DADs around the volcano; however, due to poor exposure, with one exception, they cannot be represented on the map in Figure 4.

\subsubsection{The EDA Unit}

The EDA is situated at the extension of the CVW edifice failure along the N-S-oriented normal fault system. The outcrops are rare and the matrix facies DAD is dominant (Figure $7 \mathrm{~b}$ ) characterized by the dominance of the matrix over the mostly angular and/or jigsaw blocks up to 1-2 $\mathrm{m}$ in size to $\mathrm{cm}$ ones. It is remarkable that the present-day fluvial system is also following a $\sim \mathrm{N}-\mathrm{S}$ orientation up to $10 \mathrm{~km}$ from the CVE unit with a step of $\sim 1 \mathrm{~km}$. This may possibly suggest that the EDA moved in a bulldozing way toward the east in the basin interior. Such bulldozing features are also known in several other situations with DADs worldwide [42-45]. 

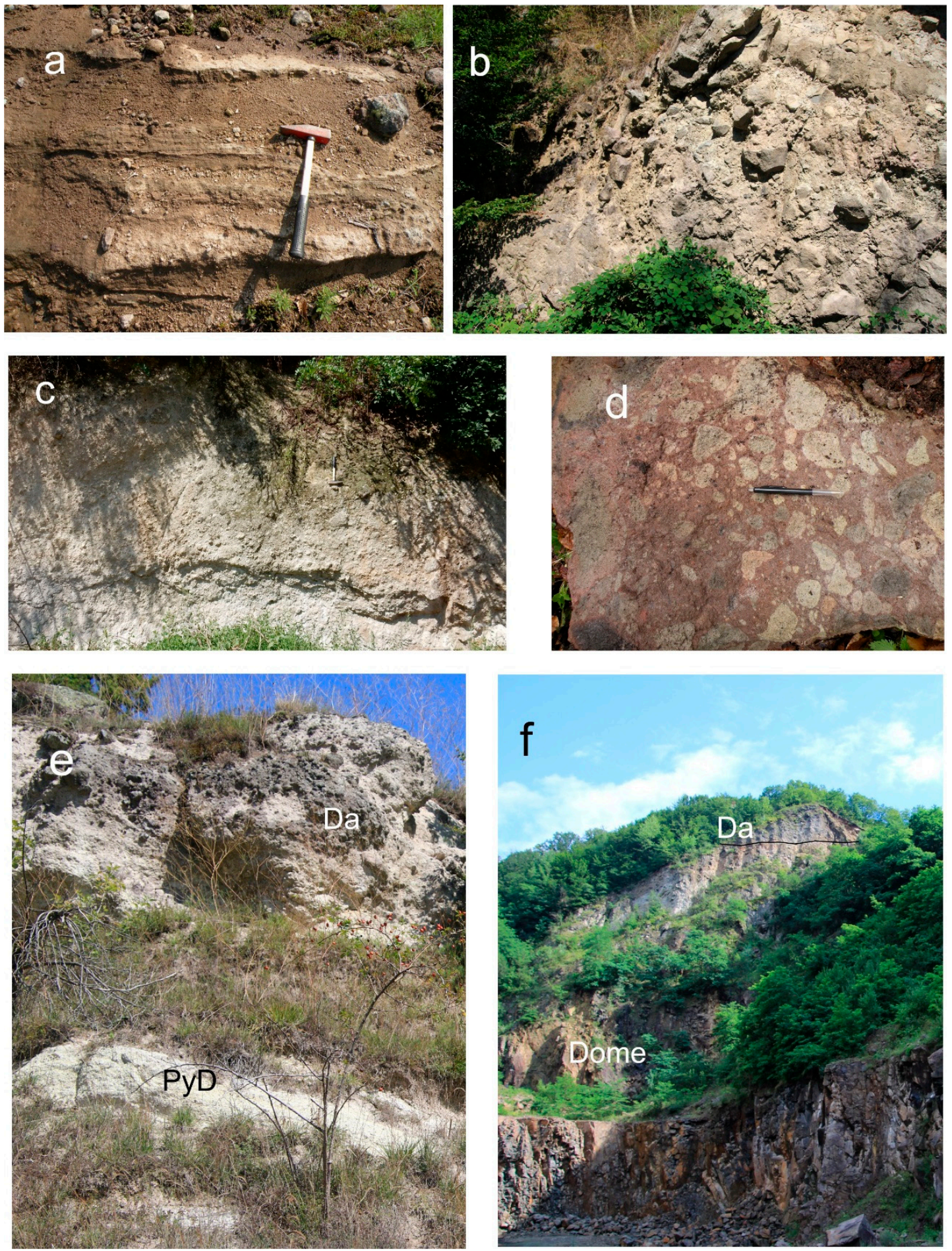

Figure 7. (a) Hyperconcentrated flows and fluvial deposits showing thin and cross-bedded sandstone showing of alternating coarse and fine layers with discontinuous lapilli trains, some with low angle cross laminations-WDA; (b) Matrix facies DAD including various size larger angular clasts -EDA; (c) Several meter thick pumiceous pyroclastic flow deposit showing $\mathrm{cm}$-dm size pumice clasts-EDA (d) Cm-dm size juvenile pumice (brighter) and scoria (darker) clasts embedded in an ash-matrix characterizing a pyroclastic block and ash flow deposit-EDA; (e) Several meter thick pumiceous pyroclastic flow deposit (PyD) that in its upper part is mingled with debris avalanche breccia (DA) showing a contorted plastic shape-SDA; (f) Debris avalanche deposits (DA) situated at the top of the Vârfuri lava Dome-NDA. 
On the right side of Criş River, there is a large outcrop of a pumiceous pyroclastic flow covered by the EDA formations (Figure 7c), suggesting an event of Plinian eruption before DAD generation. The EDA unit close to the CVW also includes several small size block and ash flow deposits of an evolved andesite, suggesting dome collapse (Figure 7d).

\subsubsection{The SDA Unit}

This unit is located to the south of the saddle between CVW and CVE showing the highest edge at $\sim 750 \mathrm{~m}$ altitude, but also the shortest length $(\sim 6 \mathrm{~km})$. Half of the southernmost part is climbing over the Mureş ophiolitic Unit basement (Figures 2 and 4). The SDA unit is poor in outcrops and those existent are of small size. It is entirely dominated by various types of DADs showing mostly pyroxene, pyroxene, and amphibole andesites lavas and amphibole bearing domes as blocks (block facies) mostly in the upper part and/or matrix-supported monolithic breccias (matrix facies) down slopes (Figure 7e). Rare outcrops of stratified thin planar and cross-bedded sandstone and siltstone suggest intrahummocky small basins. At the bottom valley level, a several-meter-thick pumiceous pyroclastic-flow deposit, similar to the one described in EDA, that is, its top, plastically mixed with DA breccia was also identified (Figure 7e). From the top to the bottom, the unit is dominated by debris-avalanche deposits, seemingly resulting from a collapsed material that destroyed the entire volcanic area between CVW and CVE and obviously associated with the collapse of the NDA unit, which was most probably generated almost simultaneously but somewhat earlier. The unit is confined akin to the N-S fault system that previously produced the CVE sliding block and associated EDA.

\subsubsection{The NDA Unit}

This unit, aligned on the N-S fault system between WVD and EVD is northward directed and situated at the continuation of the NDD area showing an evident horseshoeshaped crater. In the proximal part up to the limit with volcanic dome structures, there is a dominant block facies DAD (Figure 4). Pyroxene and amphibole andesites lavas and amphibole bearing dome types are the most dominant blocks and fragments. Remnants of debris-avalanche deposits can be found at the top of the Aciuța and Vârfuri Dome cluster (Figure 7f) suggesting that the failure event is younger and at a higher elevation than the Aciuţa and Vârfuri Domes. At the north of the present-day Criş River, the NDA shows dominant matrix facies and is associated with debris-flow deposits. On the left side of the Criş River, between Gurahonţ and Aciuţa lava Dome complexes, there is the largest area $(1.5 \mathrm{~km}$ in diameter) suggesting a former basin whose stratified thin ( $\mathrm{cm}$ up to rarely meter size) deposits are dominated by planar and cross-bedded sandstone and siltstone. In all other DAD Units, such types of secondary deposits were considered as related to intra-hummocky basins, however always of much smaller sizes; Lithological considerations and geological mapping suggest that this large basin is situated at the limit between EDA and NDA, as surely post-DAD generated in a morphological depression generated at the limit between two DAD events (Figure 4). This basin was previously recognized by [38] as a volcano-sedimentary complex, however older than the lavas of the CVW volcano remnant.

On the Pleşcuţa tributary of the Criş River, there is a $\sim 10 \mathrm{~m}$ thick pumiceous pyroclasticflow deposit that further north is covered by the DADs and associated debris flow deposits. The pyroclastic flow deposit is similar to that found in the EVD and SVD and looks as if it was generated during a Plinian collapse eruption before DADs formations. It is difficult to predict the time of the Plinian eruption, however, since all the pyroclastic flow deposits show similar features, as below DADs, it is likely that this represents an earlier event, most probably a short time before the removal of the top of the edifice dominant by amphibole ( \pm pyroxene)-bearing domes and generation of EDA and WDA that propagated to the $\mathrm{E}$ and $\mathrm{W}$ directions. 


\subsection{Geometry and Volume Calculations}

This is the first calculation of the volumes of the Bontău volcanic complex, including edifice remnants, associated lava Domes, and the DADs with the intention to reconstruct the initial edifice (Table 1). The volume calculation used a 3D terrain grid (DEM) generated by digitizing topographic maps of the study area at the scale 1:25,000. The Dealul Piscului 1979/Stereo 70 coordinate reference system was used. The central edifice remnants cover around 40.65 square $\mathrm{km}$ and the DADs cover an extensive area around the former volcano edifice; around 346.14 square $\mathrm{km}$. Two DADs units surrounding the remnants of the former volcanic edifice are E-W directed (EDA, WDA) and the other two are N-S directed (NDA, SDA) (Figure 4). The largest unit is the EDA and it is characterized by the highest length runout of DADs $(\sim 19 \mathrm{~km})$ filling the Zărand basin interior. The calculations took into account the Pliocene-Quaternary erosion processes including the Criş River and its tributaries. According to the volume calculations, we reconstructed the volcano edifice that was most probably oval in shape and had a base axis of $12 / 8 \mathrm{~km}$ (Figure 4 ) reaching the height of $\sim 2096 \mathrm{~m}$ using the [46] model. The original edifice had a similar size to the other known composite volcanoes (e.g., Ruapehu volcano, North Island, New Zealand; [47]).

Table 1. Main morphological characteristics of the Bontău volcanic complex (the height measurement were averaged for each situation).

\begin{tabular}{|c|c|c|c|c|}
\hline Volcano Edifice Remnants & Length km & Wide km & Area $\mathrm{km}^{2}$ & Volume $\mathrm{km}^{3}$ \\
\hline NDD-central & 3.5 & 1.5 & 6.049 & 1.509 \\
\hline CVE-eastern & 6.1 & 5.0 & 23.500 & 8.675 \\
\hline CVW-western & 6.3 & 2.3 & 11.104 & 5.132 \\
\hline Total volcano remnants & & & 40.654 & 15.316 \\
\hline Lava Domes complex & Length-km & Wide-km & Area $\mathrm{km}^{2}$ & Volume $\mathbf{k m}^{3}$ \\
\hline Gurahonţ & 6 & 2.3 & 15.020 & 1.766 \\
\hline Aciuţa & 3.4 & 1.6 & 4.888 & 0.394 \\
\hline Vârfuri & 3.7 & 3.3 & 11.426 & 2.0833 \\
\hline Total Lava Dome & & & 31.334 & 4.243 \\
\hline DADs & Length-km & Wide-km & Area $\mathbf{k m}^{2}$ & Volume $\mathrm{km}^{3}$ \\
\hline EDA & 19 & 10 & 114.855 & 16.225 \\
\hline WDA & 10.8 & 11.5 & 72.193 & 14.094 \\
\hline NDA & 16.2 & 13.4 & 121.642 & 17.71 \\
\hline SDA & 6 & 8 & 37.454 & 5.188 \\
\hline Total DADs & & & 346.14 & 53.217 \\
\hline Total presumed Bontău volcanic complex volume & & & & 72.776 \\
\hline
\end{tabular}

\section{Petrography}

\subsection{Basaltic Andesites}

Basaltic andesites occur as lavas only in the CVE part of the Bontău volcano. Basaltic andesites are either strongly porphyritic (clinopyroxene as phenocrysts), with 40-70 vol.\% of microphenocrysts. Plagioclase is the dominant phase. Clinopyroxene is the principal mafic mineral occurring as single crystals, but also in aggregates with inclusions (opaque minerals, apatite), orthopyroxene, and plagioclase (Figure 8a). Plagioclase phenocrysts are smaller in size $(<0.2$ to $3 \mathrm{~mm}$ ) with respect to clinopyroxene (Figure $8 \mathrm{a})$, and occasional show sieve-textured cores and oscillatory zoning. Clinopyroxene phenocrysts show high modal abundances ( 35-40 vol.\%) and large grain size, with the largest phenocrysts as $5 \mathrm{~mm}$. 

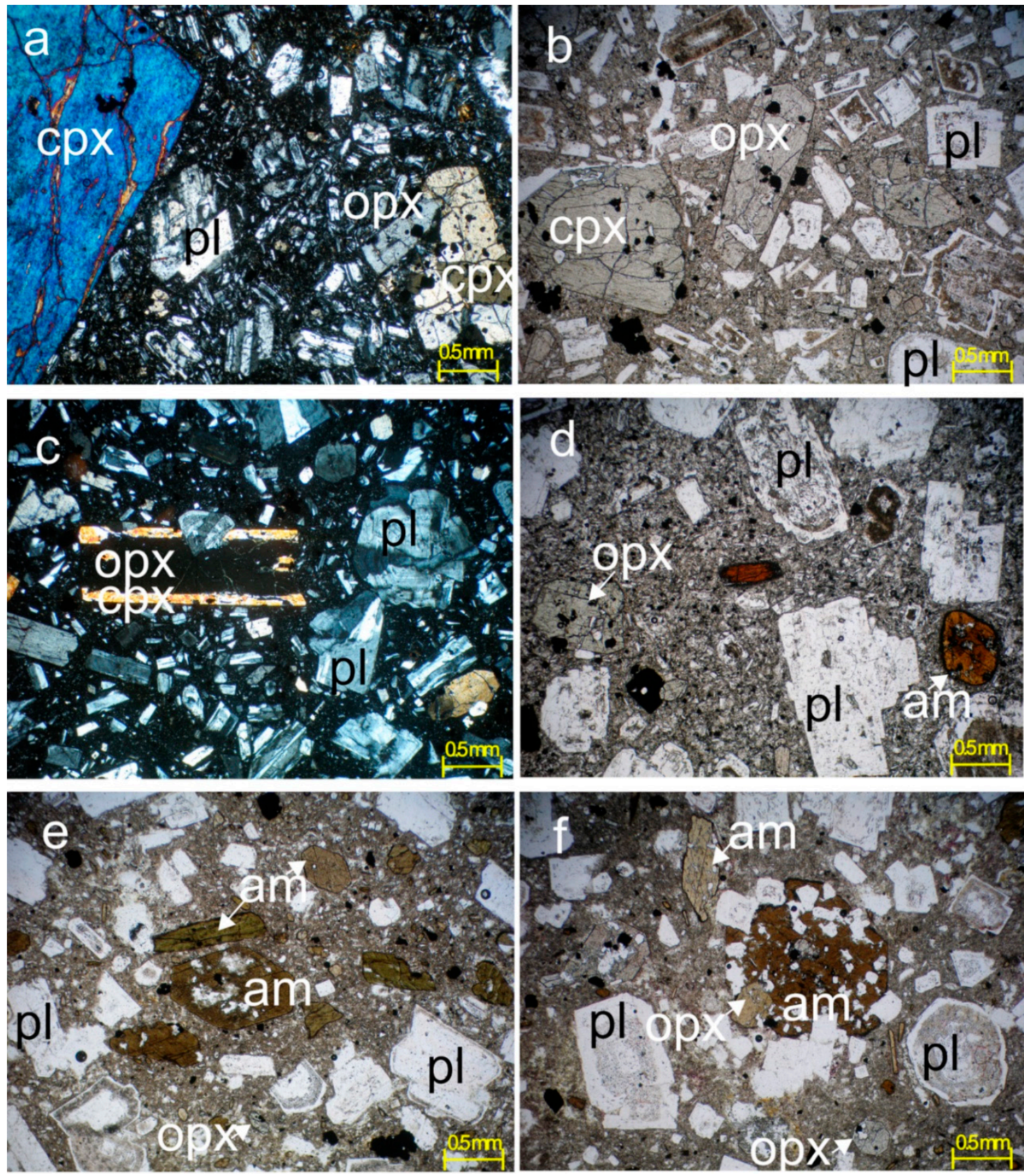

Figure 8. (a) Basaltic andesite showing large clinopyroxene (cpx) crystals, smaller plagioclase phenocrysts (pl), orthopyroxene (opx) in an aggregate with cpx and pl in a microgranular groundmass; crossed nicols-CVW; (b) Two pyroxene andesites with microgranular-hyalopilitic groundmass; parallel nicols-NDA; symbols as in (a); (c) Clinopyroxene overgrows at the margin of orthopyroxene in two pyroxene andesite; crossed nicols-CVW; (d) Pyroxene and amphibole (am) andesite with microgranular-hyalopilitic groundmass; parallel nicols-WDA; symbols as in (a); (e) Amphibole ( \pm pyroxene) andesite hyalopilitic groundmass; parallel nicols-NDA; symbols as in (a); (f) Amphibole megacryst (am) with inclusions of plagioclase (pl) and orthopyroxene (opx), but also as individual amphibole (am) crystals in amphibole ( \pm pyroxene) andesite; parallel nicols-WDA; symbols as in (a).

Orthopyroxene is rare and shows low abundance $(\sim 1 \%)$ ranging in size from 0.2 to $0.4 \mathrm{~mm}$. Some crystals are surrounded by reaction rims of clinopyroxene and include opaque minerals. The groundmass is microgranular $(0.1-0.01 \mathrm{~mm})$ hyalopilitic and contains crystals and aggregates of plagioclase, clinopyroxene, orthopyroxene, and opaques. 


\subsection{Andesites}

Andesite is the most common and volumetrically dominant rock type. Andesites display several varieties based on the phenocryst association. Two-pyroxene varieties prevail and, together with amphibole-two-pyroxene, have been found in lava flows. The amphibole ( \pm pyroxene) andesite occurs always associated with dome facies and was found only in $\mathrm{DAD}$. The rocks are close to strongly porphyritic, with a phenocryst assemblage dominated by plagioclase, followed either by pyroxene (clinopyroxene and orthopyroxene) or amphibole.

The pyroxene phenocrysts range up to $1 \mathrm{~cm}$ in maximum dimension, with an average size between 3 and $5 \mathrm{~mm}$, with abundances from 20 to 40 vol.\% (Figure 8b). All plagioclase phenocrysts show well-developed polysynthetic twinning and many show zoning; most crystals have distinctive outer or inner resorption zones surrounded by clear rims, while others have sieved altered cores densely clouded by very fine-grained $(<0.02 \mathrm{~mm})$ phyllosilicates and opaque minerals. Most of the rocks also contain aggregates (crystal clots) of pyroxene. Some individual orthopyroxenes are surrounded by overgrows of clinopyroxene (Figure 8c).

In the two-pyroxene varieties, clinopyroxene and orthopyroxene are present in almost equal amounts (Figure 8b) and are the dominant phenocryst phases ( $<0.05$ to $2 \mathrm{~mm}$ in size), while in the amphibole-bearing andesites clinopyroxene prevails. Amphibole is a major phenocryst phase in the amphibole-bearing lithologies; reddish-brown or dark green in color and range in size from $<0.05$ (microphenocrysts) to $7 \mathrm{~mm}$ (phenocryst) (Figure 8d,e). Crystals often have dark brown oxidized margins or altered/resorbed cores. Crystal aggregates of amphibole show inclusions of orthopyroxene and plagioclase (Figure 8f). Opaque minerals are generally $<0.3 \mathrm{~mm}$ in size, and rarely go up to $0.6 \mathrm{~mm}$. The groundmass is rich in microlites (plagioclase, clinopyroxene, orthopyroxene) and glass.

\section{Geochemistry}

A total of 34 new samples were analyzed for major and trace element data (Supplementary Table S1).

\subsection{Rock Classification}

We separated the rocks in the diagrams according to their volcanological characteristics (complex volcanic Domes, remnants of the composite edifice, and blocks in DADs) and added the rocks of the Zărand-Brad-Zlatna basin for evaluation (Group 1-Z; [3]) where the Bontău volcanic complex developed. According to the TAS and Peccerillo and Taylor diagrams, the samples range from basaltic andesite to andesite (Figure 9). The data are comparable with those already published before for the Bontău volcanic complex [2,20,41,48], however, the Bontău rocks show faintly lower $\mathrm{K}_{2} \mathrm{O}$ than most of the previously published data of Group 1-Z, but similar $\mathrm{Na}_{2} \mathrm{O}+\mathrm{K}_{2} \mathrm{O}$ trend. The basaltic andesites are in the smallest amount, they were identified for the first time in the remnant of the CVW edifice and were mentioned as clasts in DADs and associated with distal WDA debris-flow deposits (e.g., [48]). They are the most primitive of Group 1-Z.

The range in $\mathrm{SiO}_{2}$ is similar for the composite volcano edifice remnants (53.4-60.6\%), slightly higher for the DADs (56.7-60.6\%), and shorter for the Domes (55.9-59.1\%). The diagrams show a minor positive correlation with $\mathrm{K}_{2} \mathrm{O}$ and $\mathrm{K}_{2} \mathrm{O}+\mathrm{Na}_{2} \mathrm{O}$. We again emphasize that amphibole ( \pm pyroxene) varieties were only collected in the DADs (see Supplementary Table S1). The highest $\mathrm{SiO}_{2}$ values of the edifice remnants were collected from the top of the CVE part of the volcano and show close composition with amphibole ( \pm pyroxene) andesites sampled from the DADs. 

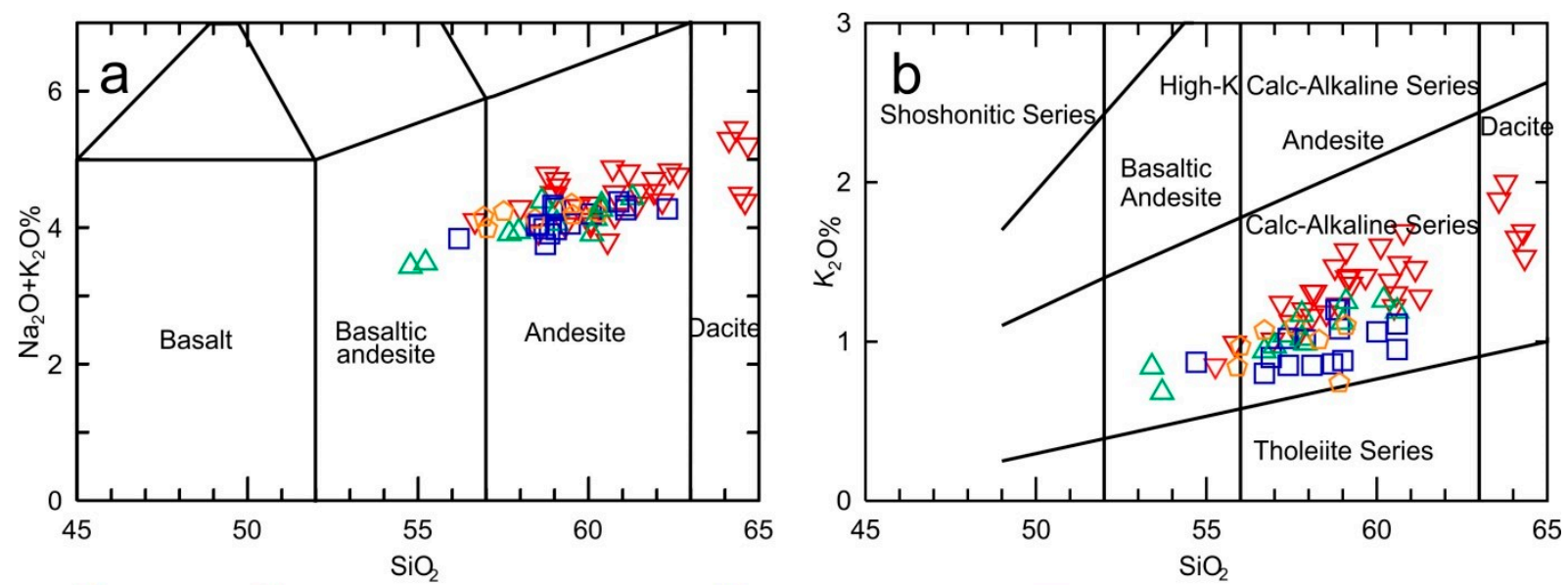

Domes; $\triangle$ Composite volcano edifice; $\square$ Debris avalanche $\nabla$ Zărand-Brad-Zlatna (Group 1-Z)

Figure 9. (a) Total alkali vs. Silica (TAS) diagram [49] and (b) $\mathrm{K}_{2} \mathrm{O}$ vs. $\mathrm{SiO}_{2}$ [50] for Bontău volcanic complex, new data, and Group 1-Z rocks [3]. All the new data are included in Supplementary Tables S1 and S2.

\subsection{Chemical and Isotopic Composition}

Major elements show rather good negative correlations in Harker diagrams for $\mathrm{Fe}_{2} \mathrm{O}_{3}$ and $\mathrm{CaO}, \mathrm{TiO}_{2}$ (not shown), and a slightly positive correlation of $\mathrm{K}_{2} \mathrm{O}$ and $\mathrm{Na}_{2} \mathrm{O}$ (Figure 10). Sc shows a negative correlation with $\mathrm{SiO}_{2}$, as other trace elements show a relatively positive correlation ( $\mathrm{Zr}, \mathrm{Hf}, \mathrm{Th}$ ), slightly higher for the dome rocks (Figure 10). There is an insignificant positive and negative Eu anomaly $\left(\mathrm{Eu} / \mathrm{Eu}^{*}=1.1-0.8\right)$ (Figure 10).

The CI-chondrite normalized rare-earth element (REE) and primitive mantle patterns [49] show small differences between sample compositions with faintly exception of $\mathrm{Nb}$ and Ta that show a lesser trough and higher HREE for the dome rocks (Figure 11) similar with the Group 1-Z rocks.

Twelve new Sr and Nd isotope analyses (Supplementary Table S1) show the initial ${ }^{87} \mathrm{Sr} /{ }^{86} \mathrm{Sr}$ and ${ }^{143} \mathrm{Nd} /{ }^{144} \mathrm{Nd}$ ratios of the Bontău volcanics varying in minor ranges, the most primitive for the basaltic andesites (0.7044 and 0.5127), then slightly higher for the andesites (0.7044-0.7054 and 0.5127-0.5125) showing a trend toward a ${ }^{87} \mathrm{Sr} /{ }^{86} \mathrm{Sr}$ increase and a ${ }^{143} \mathrm{Nd} /{ }^{144} \mathrm{Nd}$ decrease toward EM II (Figure 12). There are no essential differences between separated symbols. Highest $\mathrm{Sr}$ and $\mathrm{Nd}$ values correspond to the measured samples collected from DADs and are representative for amphibole ( \pm pyroxene) andesitic compositions. The isotopic values fall in the field of the calc-alkaline basalts in the Carpathian-Pannonian Region [22]. The most primitive rocks of the Bontău volcanics show similar isotopic values as Group 1.2-S, Group 2-N, and Group 3-S of [3], making it evident that Apuseni magmas are isotopically the most primitive in the Carpathian-Pannonian Region (e.g., [22]). The range of new data of the Bontău volcanics, some more primitive, fits in the trend of the previous data of Group 1-Z, suggestive of assimilation-fractional crystallization (AFC) processes. 

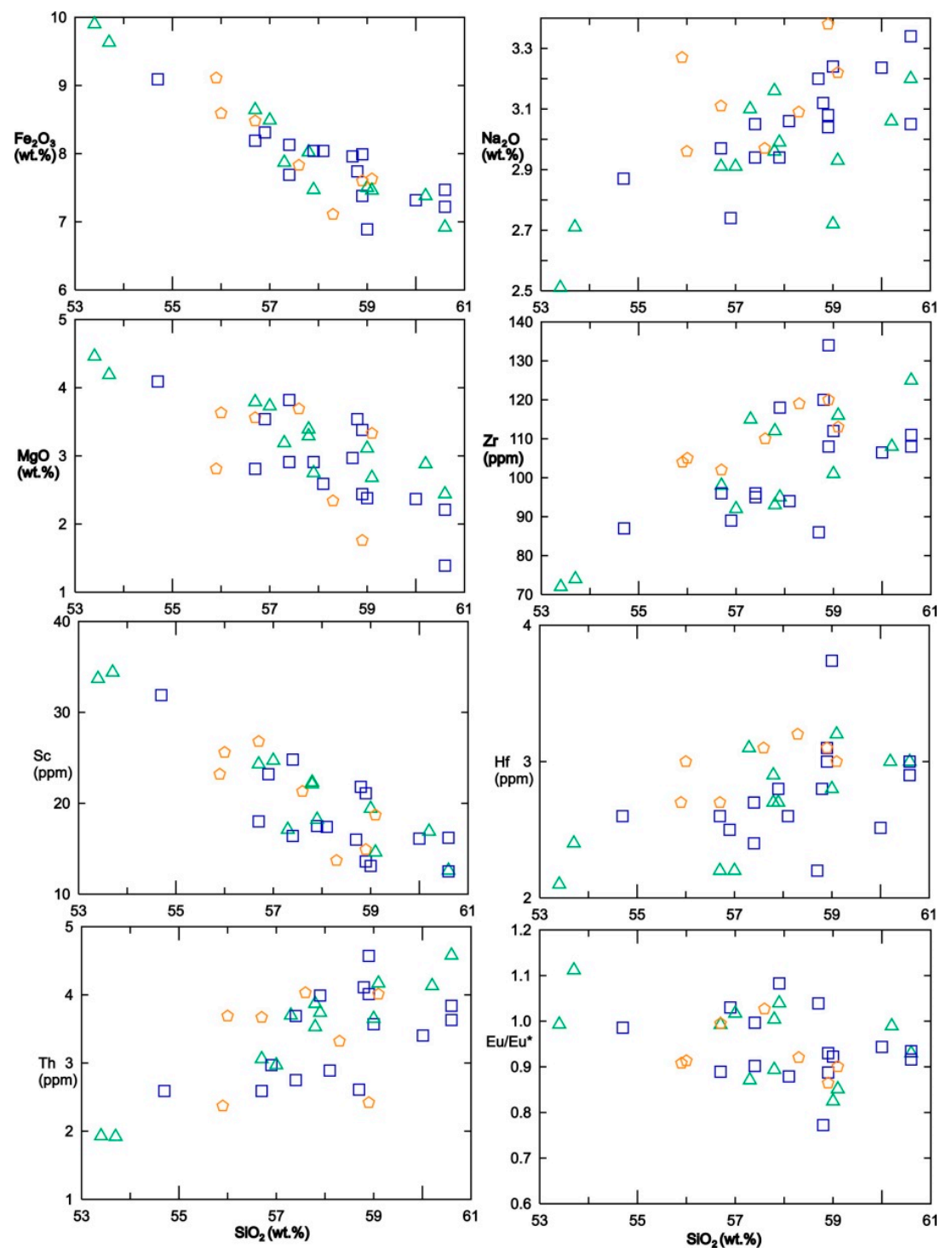

Figure 10. Major and trace elements Harker-type variation diagrams for the Bontău volcanic complex. Symbols and source of the data as in Figure 9.
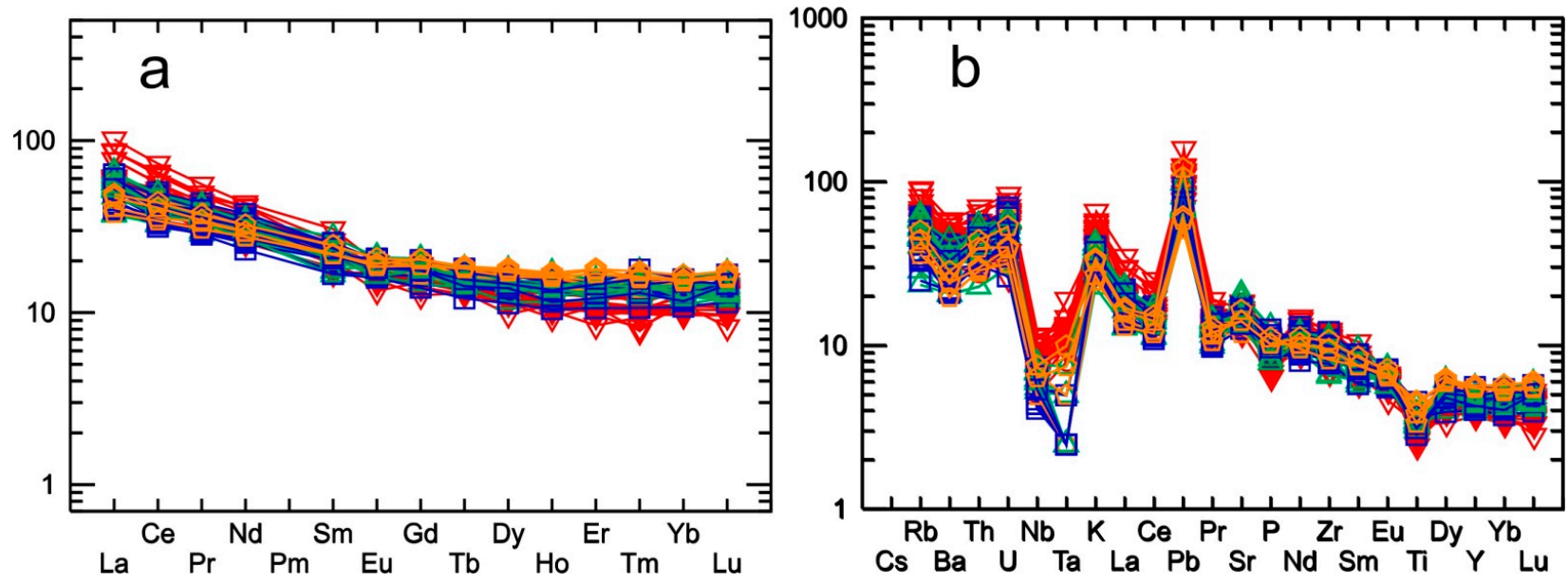

Figure 11. (a) CI Chondrite-normalized REE diagrams and (b) primitive mantle-normalized multielement diagrams for the analyzed igneous rocks of the Bontău volcanic complex and Group 1-Z rocks [3]. Symbols and source of the data as in Figure 9. The normalizing values are from [51]. 


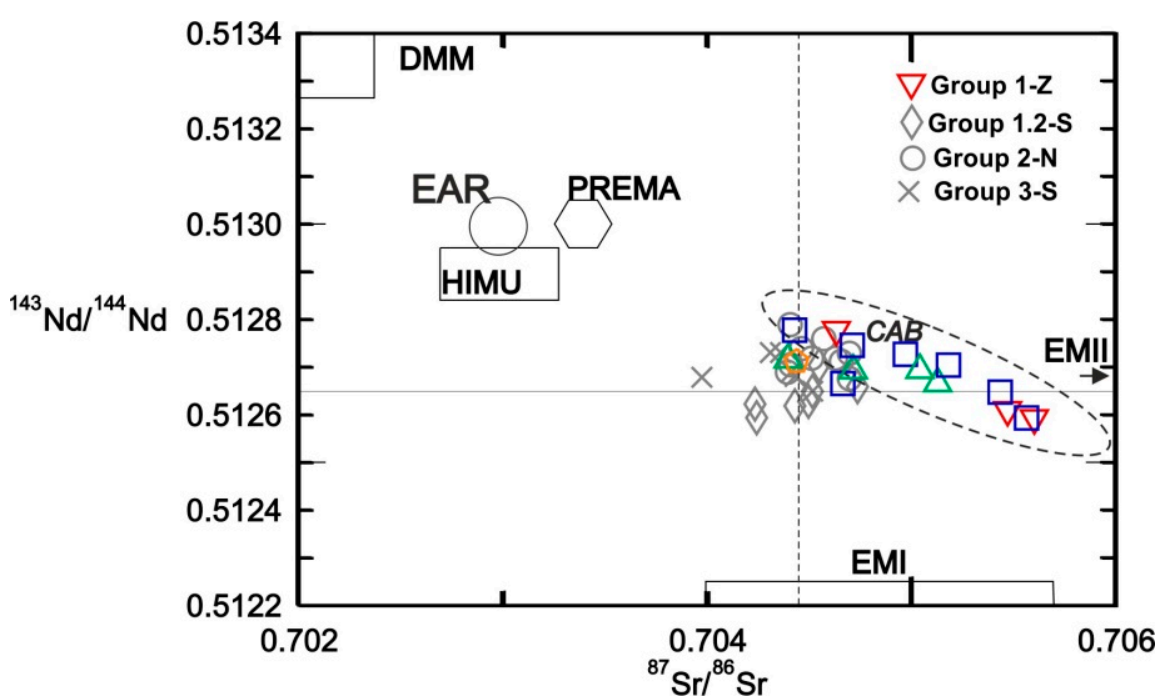

Figure 12. Isotopic characteristics of Bontău volcanic complex relative to the mantle components defined by [52] and the European Asthenospheric Reservoir (EAR) defined in [53,54]. Symbols and source of the data as in Figure 9. CAB defines the field of the calc-alkaline basalts in the Carpathian Pannonian Region after [22]. Data of the Groups 1-Z, 1.2-S, 2-N, and 3-S from [3].

\subsection{Petrogenetic Aspects}

Recent studies [3] based on petrography, geochemistry, and isotopic data suggested for Apuseni Miocene magmatism that include Bontău volcanic complex, a continuous open-system evolution of a parental mantle/crustal-derived magma in the deeper parts of the crust ([55]; 'MASH zone' of [56]) that further experienced fractional crystallization of amphibole and pyroxene (Figure 13a,b) and magma mixing processes regarding the variation of $\mathrm{SiO}_{2}$ for the same $\mathrm{Rb} / \mathrm{Sr}$ ratio of the Groups 1-Z (Figure 13a, see also Figure 10d in [3], as well as assimilation of the upper crust (Figures 12 and 13a,c).

The geochemical and isotopic data along the petrogenetic explanations support the volcanological interpretations. All the volcanic forms show a similar source, no matter whether they belong to early individual/cluster lava Domes or Bontău volcano. The most evolved rocks represented by amphibole ( \pm pyroxene) andesite are the most affected by AFC processes (Figure 13c) since these rocks were sampled only in the DADs. This proves that the original top of the volcano was formed essentially by the domes that become unstable, collapsed, and generated debris avalanches. 

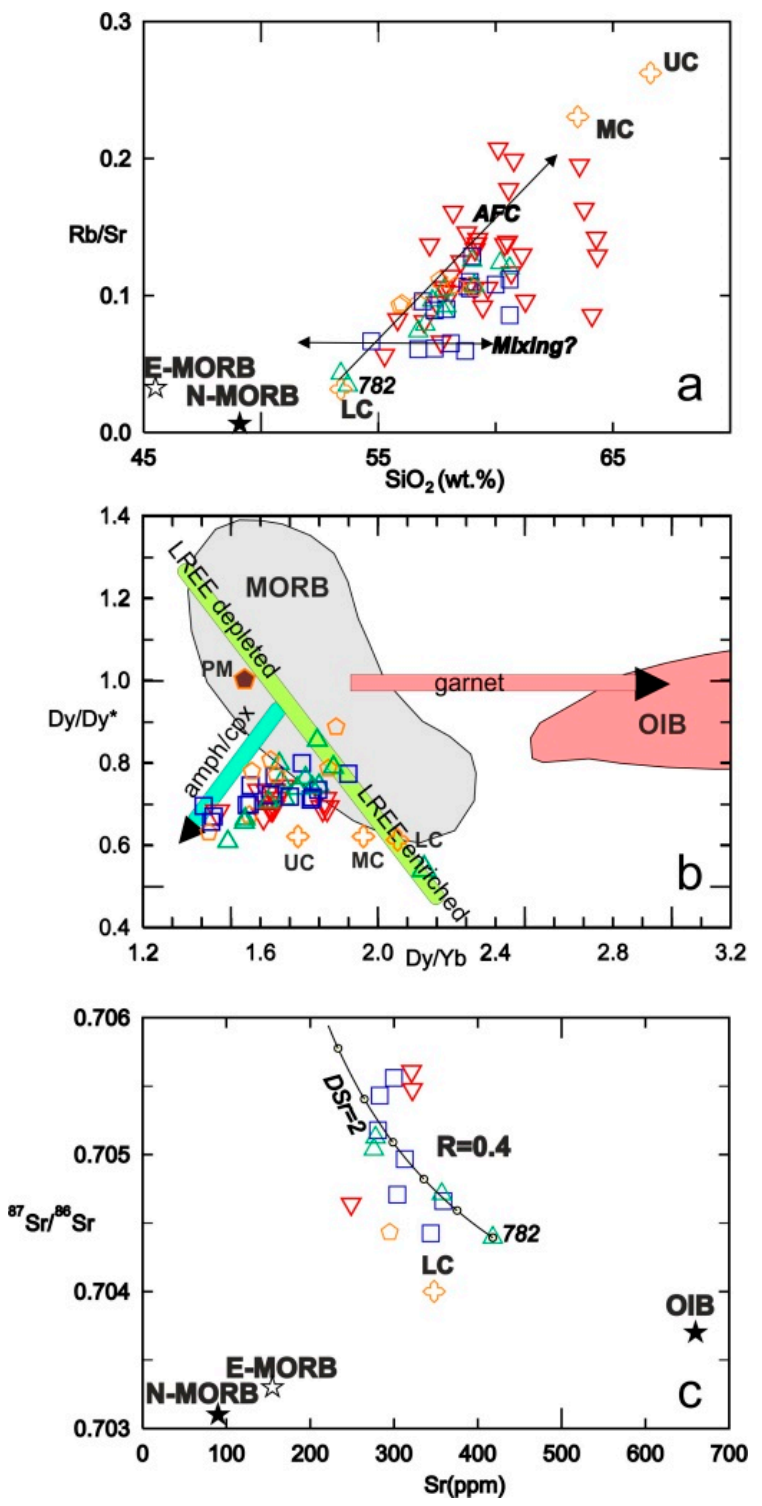

Figure 13. (a) $\mathrm{SiO}_{2}$ vs. $\mathrm{Rb} / \mathrm{Sr}$ for the Miocene magmatic rocks of Bontău volcano rock; LC-Lower crust; MC-Middle crust; UC-Upper crust after [57]; NMORB (black star) after [49]. Red triangles of the Groups 1-Z from [3]; (b) Plot of Dy/Dy* vs. Dy/Yb [58] to show fields for MORB and OIB, PM (primitive mantle) [49]; Vectors for mineral control and melting are indicative of amphibole and clinopyroxene via decrease of $\mathrm{Dy} / \mathrm{Dy}^{*}$, and $\mathrm{Dy} / \mathrm{Yb}$ also similar for the typical calc-alkaline rocks in the Bontău volcano that as well suggest a linear trend from MORB at higher Dy/Dy* to lower $\mathrm{Dy} / \mathrm{Yb}$. Red triangles are plots of previous data for the Bontău volcano [20]; [41]; (c) ${ }^{87} \mathrm{Sr} /{ }^{86} \mathrm{Sr}$ vs. Sr assimilation-fractional crystallization (AFC) modeling using [59] software starting from the most primitive basaltic andesite (sample782). Symbols and source of the data as in Figure 9. Red triangles of Groups 1-Z from [3].

\section{Discussion}

\subsection{Edifice Construction Processes and Relationships with Tectonic Developments}

Field observations suggest that the volcanic forms in the western part of the Zărand Basin were mostly generated directly on the regional basement of the graben system as following the main fault system. The volcanic forms were dominated by individual/complex lava Domes, but as well by the generation of the Bontău composite volcano. It seems that in an initial period of volcanism the lava Domes and Bontău composite volcano grew up 
simultaneously most probably up to $12.3 \mathrm{Ma}$, as the youngest K/Ar age determinations achieved in the lava Domes [2,20,36].

During the second period of volcanism, as the last stage of activity, the eruptive activity continued only in the Bontău volcano and has been characterized by repetitive growth of summit domes, which generated block-and-ash flows that flooded the upper slopes of the early composite volcano. The high volume addition of the summit domes and associated pyroclastic deposits created the condition for lastly collapse and the initial events of DADs generation. The presence of DADs at the top of the Vârfuri lava Dome complex is confirming this assumption. Younger $\mathrm{K} / \mathrm{Ar}$ ages up to $10.2 \mathrm{Ma}$ [2] may suggest the time of such volcanic forms generation is the youngest.

The two main periods of volcanism in the Bontău volcano can be connected with the geotectonic evolution of the Zărand Basin during Miocene times [3,20,31]. The first period is related to rotation-induced transtensional extension that started $\sim 16 \mathrm{Ma}$ and lasted up to 12.3-12.1 Ma with numerous normal and listric fault generation (e.g., [12,13]. The second period of volcanism, younger than $12 \mathrm{Ma}$ can be connected to a change of the tectonic system to an NW-SE compressional/transpressional tectonics (e.g., [31]), also correlated to the end of the rotation and collision initiation in the East Carpathians (e.g., [60]).

\subsection{Causes of Edifice Collapse and DADs Emplacements Processes}

There are described numerous instability factors for composite volcanoes in the literature (e.g., [61,62]). The initial instability in the case of Bontău was a result of the high viscosity and high water content of the ascending magma (amphibole-bearing andesites), as the most likely trigger mechanism possibly associated with shallow-focus volcanic earthquakes.

The late-stage dome generation most likely favored the edifice destabilization via increased edifice pore pressure along the N-S direction fault system released from a viscous ascending magma. This may explain the CVE eastward sliding as a large collapse block followed by EDA deposition up to more than $20 \mathrm{~km}$ from the inferred vent area (Figure 4). Ref [45] described a similar situation at Shiveluch volcano, where an abrupt increase of magma viscosity and the production of lava domes triggered disturbance of the volcanic edifice that collapsed, however in that case the Plinian eruptions accompanied by fountain collapse and the emplacement of pumice flows followed the slope failure.

The field observations, regarding the presence of pumiceous pyroclastic flow covered by DADs, suggest an event of Plinian eruption before DAD generation. The Plinian eruption and large volume summit domes and associated block-and-ash flows destabilized the top of the volcano creating the conditions for the final dismantling and DADs generation. Debris flows occur simultaneously in the medial facies, most probably connected with the rain events.

The succession of DADs events suggests almost simultaneous E-W EDA and WDA generation that created the conditions for WDA edifice spreading along $\sim \mathrm{N}-\mathrm{S}$ fault system. It is possible that WDA flank failure to be a substrate response (e.g., $[43,63])$ as the volcano was generated at the ENE-WSW geological boundary between two main units (Biharia and Mureş ophiolitic unit) and a series of NW-SE crossing faults (Figures 2 and 4). Substrate bulldozing on the Mureş ophiolitic unit substrate of the EDA DADs can explain the parallel medial to distal "ridges" (presently underlined by transversal parallel valleys) with the similar $\sim \mathrm{N}-\mathrm{S}$ orientation as the parallel faults flanking the CVE ridges, considering also that the EDA DA unit, however, eroded, suggest an almost uniform thickness in medial to distal facies.

The volcano spreading condition along $\sim \mathrm{N}-\mathrm{S}$ oriented faults destabilized the edifice between CVE and CVW (central NDD area) that further collapsed toward the south (SDA) and then north (NDA) creating the collapsed area of NDD as a north-oriented horseshoeshaped-like debris avalanche crater, the younger-most process in the destruction processes of the volcano. It is visible that the Vârfuri Dome acted as a barrier for the NDA, so most of the DADs were oriented to its western side and some covered its top (Figure 4). We suppose that Aciuţa Dome, as situated in the main direction of the NDA was as well covered by 
debris-avalanche deposits, but most probably such deposits have been afterward eroded (Figure 4).

\subsection{Post Destruction Processes}

All the DADs besides blocking the entire graben systems between the Mures ophiolitic unit at the south and the Biharia and Codru units comprise at different levels small basins (not mapped) with lacustrine and fluviatile sedimentation which we supposed to be generated in a hummocky topography. The largest of such situated at the limit between EDA and NDA cannot be taken as an intra-hummocky depression, but as a post DADs filled depression formed at the limit between the mentioned DADs events. The PlioceneQuaternary erosion acted up to the present morphology landscape. It is notable that Criş River crossed the valley toward the west on the E-W fault direction where the Gurahont, Aciuţa and Vârfuri Domes were generated, at the north of Bontău composite volcano and helped a better exposure of the lava Domes.

\section{Conclusions}

The Bontău volcanic complex (including Bontău volcano and the Gurahonţ, Aciuţa and Vârfuri Domes) is located in the western part of the Zărand graben, as a E-W-oriented structure. The andesitic Bontău volcano consists of two N-S-oriented remnants of the largest andesitic stratovolcano in the Zărand basin as initiated at $~ 14 \mathrm{Ma}$ and ended at 10 Ma. The stratovolcano had two stages; the first effusive-explosive generated at the same time with the Gurahonţ, Aciuţa, and Vârfuri lava Domes up to 12 Ma. The second stage, after $\sim 12$ Ma started with a Plinian eruption and then continued with extrusive dome generation further associated with gravitational collapses, emplacing massive DADs, widely distributed all around the volcano. Four DADs units are defined, corresponding to collapsed structures directed initially to the west and east and then to the south and north. The construction and destruction of the volcano have been also been affected by basement substrate, and the movement of the E-W and NW-SE-oriented faults, which contributed to the destabilization and collapse of the volcanic edifice. In the E-W direction, the DADs surface shows small hills with smooth slopes and heights of less than $20 \mathrm{~m}$, elongated perpendicular to the flow direction suggesting substrate bulldozing. In the $\mathrm{N}-\mathrm{S}$ direction the DADs climb on the raised basement tectonic margins of the graben. Small basins where lacustrine and fluviatile sedimentation occurred suggest a hummocky topography of the DAD units. A larger lacustrine basin was recognized at the limit between EDA and NDA. The volume calculations suggest similarities with composite volcanoes worldwide.

The geochemical and isotopic data confirm the previous studies on the source and evolution of magmas via assimilation-fractional crystallization $[2,20]$ and attest the amphibole ( \pm pyroxene) andesites, found only in DADs, as the most evolved.

Supplementary Materials: The following supporting information can be downloaded at: https: / / www.mdpi.com/article/10.3390/min12020243/s1, Figure S1: Photo details of the Domes; Figure S2: Photo details of the DADs; Table S1: New geochemical and isotopic data; Table S2: Sr and Nd data with 2SD and methodology comments.

Author Contributions: Conceptualization, I.S.; methodology, I.S. and V.M.M.; software, V.M.M. and I.S.; validation, I.S.; formal analysis, I.S.; investigation, G.C.Ş., I.S. and V.M.M.; resources, I.S., V.M.M. and G.C.S., data curation, I.S. and V.M.M.; writing-original draft preparation, I.S.; writingreview and editing, I.S. and V.M.M.; visualization, V.M.M. and G.C.Ş.; supervision, I.S.; project administration, I.S.; funding acquisition, I.S. All authors have read and agreed to the published version of the manuscript.

Funding: A grant of Ministry of Research and Innovation, CNCS-UEFISCDI, project number PN-IIIP4-IDPCCF-2016-4-0014, within PNCDI III is acknowledged.

Acknowledgments: A grant of Ministry of Research and Innovation, CNCS-UEFISCDI, project number PN-III-P4-IDPCCF-2016-4-0014, within PNCDI III is acknowledged. We would like to thank two anonymous reviewers for constructive comments that significantly improved the manuscript. 
Conflicts of Interest: The authors declare no conflict of interest.

\section{References}

1. Davidson, J.; de Silva, S. Composite Volcanoes. In Encyclopedia of Volcanoes; Sigurdsson, H., Houghton, B.F., McNutt, S.R., Rymer, H., Stix, J., Eds.; Academic Press: San Diego, CA, USA, 2000; pp. 663-681.

2. Seghedi, I.; Szakács, A.; Roşu, E.; Pécskay, Z.; Gmeling, K. Note on the evolution of a Miocene composite volcano in an extensional setting, Zărand Basin (Apuseni Mts., Romania). Cent. Eur. J. Geol. 2010, 2, 321-328. [CrossRef]

3. Seghedi, I.; Ntaflos, T.; Pécskay, Z.; Panaiotu, C.; Mirea, V.; Downes, H. Miocene extension and magma generation in the Apuseni Mts. (western Romania): A review. Int. Geol. Rev. 2021, 1-27. [CrossRef]

4. Voight, B.; Glicken, H.; Janda, R.J.; Douglass, P.M. Catastrophic Rockslide Avalanche of May 18. In The 1980 Eruptions of Mount St. Helens; Lipman, P.W., Mullineaux, D.R., Eds.; Professional Papers; United States Geological Survey: Washington, DC, USA, 1981; Volume 1250, pp. 347-378.

5. Glicken, H. Rockslide-Debris Avalanche of May 18, 1980, Mount St. Helens Volcano, Washington; Open-file Rep 96-677; US Geological Survey: Vancouver, WA, USA, 1996; pp. 1-90.

6. Siebert, L.; Roverato, M.A. Historical Perspective on Lateral Collapse and Volcanic Debris Avalanches. In Volcanic Debris Avalanches. Advances in Volcanology (An Official Book Series of the International Association of Volcanology and Chemistry of the Earth's Interior); Roverato, M., Dufresne, A., Procter, J., Eds.; Springer: Cham, Germany, 2021. [CrossRef]

7. Cortés, A.; Macías, J.L.; Capra, L.; Garduño-Monroy, V.H. Sector collapse of the SW flank of Volcán de Colima, México. The 3600 yr BP La Lumbre-Los Ganchos debris avalanche and associated debris flows. J. Volcanol. Geotherm. Res. 2010, 197, 52-66. [CrossRef]

8. Capra, L.; Gavilanes-Ruiz, J.C.; Bonasia, R.; Saucedo-Giron, R.; Sulpizio, R. Re-assessing volcanic hazard zonation of Volcán de Colima, México. Nat. Hazards 2015, 76, 41-61. [CrossRef]

9. Siebe, C.; Komorowski, J.C.; Sheridan, M.F. Morphology and emplacement of an unusual debris-avalanche deposit at Jocotitlán volcano, Central Mexico. Bull. Volcanol. 1992, 54, 573-589. [CrossRef]

10. Dumitrescu, I.; Săndulescu, M. Harta Tectonică a României (Tectonic map of Romania). In Geological Atlas of Romania; Geological Institute of Romania: Bucharest, Romania, 1976.

11. Balintoni, I. Structure of the Apuseni Mountains. Rom. J. Tecton. Reg. Geol. 1994, 75 (Suppl. 2), 51-58.

12. Săndulescu, M. Cenozoic Tectonic History of the Carpathians in The Pannonian Basin: A Study in Basin Evolution; Royden, L., Horvath, F., Eds.; AAPG Memoir: Tusla, OK, USA, 1988; Volume 45, pp. 17-25.

13. Balázs, A.; Maţenco, L.; Magyar, I.; Horváth, F.; Cloetingh, S. The link between tectonics and sedimentation in back-arc basins: New genetic constraints from the analysis of the Pannonian Basin. Tectonics 2016, 35, 1526-1559. [CrossRef]

14. Tari, G.; Dovenyi, P.; Dunkl, I.; Horvath, F.; Lenkey, L.; Ştefănescu, M.; Szafian, P.; Toth, T. Lithospheric structure of the Pannonian Basin Derived from Seismic, Gravity and Geothermal Data. In the Mediterranean Basins: Extension Within the Alpine Orogen; Durand, B., Jolivet, L., Horvath, F., Serrane, M., Eds.; The Geological Society of London-Special Publications: London, UK, 1999; Volume 156, pp. 215-250.

15. Fodor, L.; Csontos, L.; Bada, G.; Györfi, I.; Benkovics, L. Tertiary tectonic evolution of the pannonian basin system and neighbouring orogens; a new synthesis of palaeostress data. Geol. Soc. Spec. Publ. 1999, 156, 295-334. [CrossRef]

16. Csontos, L.; Nagymarosy, A. The Mid-Hungarian line; a zone of repeated tectonic inversions. Tectonophysics 1998, $297,51-71$. [CrossRef]

17. Ghiţulescu, T.P.; Socolescu, M. Étude géologique et minière des Monts Metallilifères (Quadrilatère aurifère et régions environnantes). An. Inst. Geol. 1941, 21, 181-464.

18. Ianovici, V.; Giuşcă, D.; Ghiţulescu, T.P.; Borcoş, M.; Lupu, M.; Bleahu, M.; Savu, H. Geological Evolution of the Metaliferi Mountains; Education Academy Rep. Society: Bucharest, Romania, 1969; 741p. (In Romanian)

19. Horváth, F.; Bada, G.; Szafian, P.; Tari, G.; Adam, A.; Cloetingh, S. Formation and deformation of the Pannonian Basin: Constraints from observational data. Geol. Soc. Lond. Mem. 2006, 32, 191-206. [CrossRef]

20. Roşu, E.; Seghedi, I.; Downes, H.; Alderton, D.H.M.; Szakács, A.; Pécskay, Z.; Panaiotu, C.; Panaiotu, C.E.; Nedelcu, L. Extensionrelated Miocene calc-alkaline magmatism in the Apuseni Mountains, Romania: Origin of magmas. Swiss Bull. Miner. Petrol. 2004, 84, 153-172.

21. Harris, C.R.; Pettke, T.; Heinrich, C.A.; Roşu, E.; Woodland, S.; Fry, B. Tethyan mantle metasomatism creates subduction geochemical signatures in non-arc $\mathrm{Cu}-\mathrm{Au}-\mathrm{Te}$ mineralizing magmas: Apuseni Mountains (Romania). Earth Planet. Sci. Lett. 2013, 366, 122-136. [CrossRef]

22. Seghedi, I.; Downes, H.; Szakács, A.; Mason, P.R.D.; Thirlwall, M.F.; Roşu, E.; Pécskay, Z.; Marton, E.; Panaiotu, C. NeogeneQuaternary magmatism and geodynamics in the Carpathian-Pannonian region: A synthesis. Lithos 2004, 72, 117-146. [CrossRef]

23. Balázs, A.; Burov, E.; Maţenco, L.; Vogt, K.; Francois, T.; Cloetingh, S. Symmetry during the syn-and post-rift evolution of extensional back-arc basins: The role of inherited orogenic structures. Earth Planet. Sci. Lett. 2017, 462, 86-98. [CrossRef]

24. Dinu, C.; Calotă, C.; Mocanu, V.; Ciulavu, D. Geotectonic setting and the particular structural features of the Beiuş basin, on the basis of geological and geophysical data synthesis. Rev. Roum. Géophys. 1991, 35, 77-87.

25. Csontos, L. Tertiary tectonic evolution of the Intra-Carpathian area: A review. Acta Volcanol. 1995, 7, 1-13.

26. Dallmeyer, R.D.; Pană, D.I.; Neubauer, F.; Erdmer, P. Tectonothermal evolution of the Apuseni Mountains, Romania: Resolution of Variscan versus alpine events with 40Ar/39Ar ages. J. Geol. 1999, 107, 329-352. [CrossRef] 
27. Pană, D.I.; Heaman, L.M.; Creaser, R.A.; Erdmer, P. Prealpine crust in the Apuseni Mountains, Romania: Insights from Sm-Nd and U-Pb data. J. Geol. 2002, 110, 341-354. [CrossRef]

28. Balintoni, I.; Balica, C.; Ducea, M.N.; Chen, F.K.; Hann, H.P.; Sabliovschi, V. Late cambrian-early ordovician gondwanan terranes in the romanian carpathians: A zircon U-Pb provenance study. Gondwana Res. 2009, 16, 119-133. [CrossRef]

29. Balintoni, I.; Balica, C.; Ducea, M.N.; Zaharia, L.; Chen, F.K.; Cliveti, M.; Hann, H.P.; Li, L.Q.; Ghergari, L. Late CambrianOrdovician northeastern Gondwanan terranes in the basement of the Apuseni Mountains, Romania. J. Geol. Soc. 2010, 167, 1131-1145. [CrossRef]

30. Szemerédi, M.; Varga, A.; Dunkl, I.; Lukács, R.; Seghedi, I.; Kovács, Z.; Raucsik, B.; Pál-Molnár, E. Petrology and zircon U-Pb dating of granitoid rocks in the Highiş massif (SW Apuseni Mts, Romania): Insights into Permian plutonic-volcanic connections. Geol. Carp. 2021, 72, 482-504. [CrossRef]

31. Neubauer, F.; Lips, A.; Kouzmanov, K.; Lexa, J.; Ivăşcanu, P. Subduction, slab detachment and mineralization: The Neogene in the Apuseni Mountains and Carpathians. Ore Geol. Rev. 2005, 27, 13-44. [CrossRef]

32. Lexa, J.; Seghedi, I.; Németh, K.; Szakács, A.; Konečný, V.; Pécskay, Z.; Fülöp, A.; Kovacs, M. Neogene-Quaternary volcanic forms in the Carpathian-Pannonian Region: A review. Cent. Eur. J. Geosci. 2010, 2, 207-270. [CrossRef]

33. Fink, J.F.; Anderson, S.W. Lava Domes and Coulees. In Encyclopedia of Volcanoes; Sigurdsson, H., Houghton, B.F., McNutt, S.R., Rymer, H., Stix, J., Eds.; Academic Press: San Diego, CA, USA, 2000; pp. 307-319.

34. Heiken, G.; Wohletz, K. Tephra deposits associated with silicic domes and lava flows. Geol. Soc. Am. Spec. Pap. 1987, 212, 55-76.

35. Kósik, S.; Németh, K.; Lexa, J.; Procter, J.N. Understanding the evolution of a small-volume silicic fissure eruption: Puketerata Volcanic Complex, Taupo Volcanic Zone, New Zealand. J. Volcanol. Geotherm. Res. 2019, 383, 28-46. [CrossRef]

36. Roşu, E.; Pécskay, Z.; Ştefan, A.; Popescu, G.; Panaiotu, C.; Panaiotu, C.E. The evolution of the Neogene volcanism in the Apuseni Mountains (Romania): Constraints from new K/Ar data. Geol. Carpath. 1997, 48, 353-359.

37. Pécskay, Z.; Lexa, J.; Szakács, A.; Seghedi, I.; Balogh, K.; Konečný, V.; Kovács, M.; Márton, E.; Zelenka, T.; Póka, T.; et al. Geochronology of neogene-quaternary magmatism in the Carpathian arc and Intra-Carpathian area: A review. Geol. Carpath. 2006, 57, 511-530.

38. Berbeleac, I.; David, M.; Zămârcă, A. Petrological and petrochemical data on the Tertiary volcanics from the eastern part of the Zărand Mountains. D.S. Inst. Geol. Geofiz. 1984, LXVIII, 27-46.

39. Berbeleac, I.; Neacșu, V.; Zămîrcă, A.; Bratosin, I. Geochemistry and mineralogy of altered rocks and pyrites associated with the porphyry copper-gold mineralization of the Tertiary subvolcanic body from Tălagiu, Zărand Mountains. Rom. J. Miner. Depos. $1992,75,55-64$

40. Berbeleac, I.; Iliescu, D.; Andrei, J.; Ciuculescu, O.; Ciuculescu, R. The relationship between alterations, porphyry copper-gold and base metal-gold hydrothermal vein mineralizations in Tertiary intrusions, Tălagiu area, Zărand Mountains. Rom. J. Miner. Depos. 1995, 76, 31-39.

41. Hindson, T. The Geology and Geochemical Signature of the Talagiu Complex, Apuseni Mountains, NW Romania. Master's Dissertation, University of Southampton, Southampton, UK, 2009; 71p.

42. Abdrakhmatov, K.; Strom, A.L. Dissected Rockslide and Rock Avalanche Deposits: Tien Shan, Kyrgyzstan. In Landslides from Massive Rock Slope Failure; NATO Science Series IV, Earth and Environmental Sciences; Evans, S.G., Scarascia-Mugnozza, G., Strom, A.L., Hermanns, R.L., Eds.; Springer: Dordrecht, The Netherlands, 2006; Volume 49, pp. 551-570.

43. van Wyk de Vries, B.; Self, S.; Francis, P.W.; Keszthelyi, L. A gravitational spreading origin for the Socompa debris avalanche. J. Volcanol. Geotherm. Res. 2001, 105, 225-247. [CrossRef]

44. Philip, H.; Ritz, J.-F. Gigantic paleolandslide associated with active faulting along the Bogd fault (Gobi-Altay, Mongolia). Geology 1999, 27, 211-214. [CrossRef]

45. Belousov, A.; Belousova, M.; Voight, B. Multiple edifice failures, debris avalanches and associated eruptions in the Holocene history of Shiveluch volcano, Kamchatka, Russia. Bull. Volcanol. 1999, 61, 324-342. [CrossRef]

46. Karátson, D.; Timár, G. Comparative volumetric calculations of two segments of the Neogene/Quaternary volcanic chain using SRTM elevation data: Implications for erosion and magma output rates. Z. Geomorphol. Suppl. 2005, 140, 19-35.

47. Hackett, W.R.; Houghton, B.F. A facies model for a quaternary andesitic composite volcano: Ruapehu, New Zealand. Bull. Volcanol. 1989, 51, 51-68. [CrossRef]

48. Zaharia, L.; Har, N.; Vlăzan, M. Geochemical investigation of Neogene volcaniclastic rocks from the south-eastern part of the Zărand Basin (Apuseni Mts., Romania)_Implications for locating the source area. Studia UBB Geol. 2016, 60, 5-15. [CrossRef]

49. Le Bas, M.J.; Le Maitre, R.W.; Streckeisen, A.; Zanettin, B. A chemical classification of volcanic rocks based on the total alkali-silica diagram. J. Pet. 1986, 27, 745-750. [CrossRef]

50. Peccerillo, A.; Taylor, S.R. Geochemistry of Eocene calc-alkaline volcanic rocks from the Kastamonu Area. Contrib. Miner. Pet. 1976, 58, 63-81. [CrossRef]

51. Sun, S.-S.; McDonough, W.F. Chemical and isotopic systematics of oceanic basalts: Implications for mantle composition and processes. Geol. Soc. Lond. Spec. Publ. 1989, 42, 313-345. [CrossRef]

52. Zindler, A.; Hart, S. Chemical geodynamics. Annu. Rev. Earth Planet. Sci. 1986, 14, 493-571. [CrossRef]

53. Cebria, J.M.; Wilson, M. Cenozoic mafic magmatism in western/central Europe. A common European asthenospheric reservoir? Terra Nova 1995, 7, 162 
54. Granet, M.; Wilson, M.; Achauer, U. Imaging a mantle plume beneath the French Massif Central. Earth Planet. Sci. Lett. 1995, 136, 281-296. [CrossRef]

55. DePaolo, D.J. Trace element and isotopic effects of combined wallrock assimilation and fractional crystallization. Earth Planet. Sci. Lett. 1981, 53, 189-202. [CrossRef]

56. Hildreth, W.; Moorbath, S. Crustal contributions to arc magmatism in the Andes of central Chile. Contrib. Miner. Pet. 1988, 98, 455-489. [CrossRef]

57. Rudnick, R.L.; Gao, S. Composition of the Continental Crust. In Treatise on Geochemistry; Turekian, K.K., Holland, H.D., Eds.; Elsevier Science: Amsterdam, The Netherlands, 2003; Volume 3, pp. 1-64.

58. Davidson, J.; Turner, S.; Plank, T. Dy /Dy*: Variations arising from mantle sources and petrogenetic processes. J. Petrol. 2013, 54, 525-537. [CrossRef]

59. Carr, M. IGPET Software Program; Terra Softa Inc.: Somerset, NJ, USA, 2014.

60. Maţenco, L.; Bertotti, G. Tertiary tectonic evolution of the external East Carpathians (Romania). Tectonophysics 2000, 316, 255-286. [CrossRef]

61. McGuire, W.J. Volcano instability: A review of contemporary themes. Geol. Soc. Lond. Spec. Publ. 1996, 110, 1-23. [CrossRef]

62. Szakács, A.; Seghedi, I. Large Volume Volcanic Debris Avalanche in the East Carpathians, Romania. In Volcaniclastic Rocks, from Magma to Sediments; Leyrit, H., Montenat, C., Eds.; Gordon Breach Science Publishers: Amsterdam, The Netherlands, 2000; pp. 131-151.

63. Dufresne, A.; Salinas, S.; Siebe, C. Substrate deformation associated with the Jocotitlán edifice collapse and debris avalanche deposit, Central México. J. Volcanol. Geotherm. Res. 2010, 197, 133-148. [CrossRef] 